\title{
Geochemistry and paleogeographic implications of Permo-Triassic metasedimentary cover from the Tauern Window (Eastern Alps)
}

\author{
Gerhard Franz $^{1}$, Martin Kutzschbach ${ }^{1}$, Eleanor J. Berryman ${ }^{2}$, Anette Meixner ${ }^{3}$, Anselm Loges ${ }^{1,4}$, and \\ Dina Schultze ${ }^{1,4}$ \\ ${ }^{1}$ Technische Universität Berlin, Chair of Applied Geochemistry, 10587 Berlin, Germany \\ ${ }^{2}$ CanmetMINING, Natural Resources Canada, Ottawa, K1A 0G1, Ontario, Canada \\ ${ }^{3}$ Faculty of Geosciences \& MARUM - Center for Marine Environmental Sciences, \\ University of Bremen, 28359 Bremen, Germany \\ ${ }^{4}$ Freie Universität Berlin, Chair of Mineralogy, 12249 Berlin, Germany
}

Correspondence: Gerhard Franz (gefra548@gmail.com)

Received: 9 April 2021 - Revised: 13 June 2021 - Accepted: 15 June 2021 - Published: 21 July 2021

\begin{abstract}
The chemical composition of metasediments is a valuable source of paleogeographic information about the protolith's sedimentary environment. Here, we compile major- and trace-element whole-rock data, including $\mathrm{B}$ contents, and ${ }^{10 / 11} \mathrm{~B}$-isotope ratios from the Permo-Triassic metasedimentary cover of the PfitschMörchner basin, overlying the Variscan basement in the western Tauern Window, Eastern Alps (Austria and Italy). The basement consists of orthogneiss ("Zentralgneis", metamorphosed Variscan granitoids with intrusion ages between 305 and $280 \mathrm{Ma}$ ), and the roof pendant consists of granites (amphibolites, paragneiss, and minor serpentinites). The Zentralgneis is partly hydrothermally altered into pyrite quartzite with high Al-S contents, low $\mathrm{Na}-\mathrm{Sr}-\mathrm{Ca}-\mathrm{Mg}$ contents, and very strong depletion of the light rare earth elements. Comparison with published detailed mapping of this and other time-equivalent basins in the western Tauern Window, with radiometric age data in the literature, and with unmetamorphosed basins in the South Alpine realm yields a late Permian to Early Triassic age of sedimentation.

Although during Alpine metamorphism all rocks were strongly deformed, the whole-rock chemical compositions of the metasediments were not pervasively changed during deformation. We show that the sediments were deposited in a small, probably lacustrine-fluviatile, intramontane basin, under arid to semi-arid climatic conditions. The sequence starts with metaconglomerates, which can be interpreted as a mixture of the different basement rocks, based on a combination of major-element ratios $\mathrm{Na}_{2} \mathrm{O} /\left(\mathrm{Na}_{2} \mathrm{O}+\mathrm{K}_{2} \mathrm{O}\right)$ and $\mathrm{MgO} /\left(\mathrm{MgO}+\mathrm{Fe}_{2} \mathrm{O}_{3}\right)$ with concentrations of trace elements $\mathrm{Cr}, \mathrm{V}$, and $\mathrm{Ni}$. The sequence is overlain by a fining-upwards sequence of clastic sediments, in which the behavior of $\mathrm{K}, \mathrm{Rb}$, and $\mathrm{Sr}$ allows the reconstruction of intense diagenetic $\mathrm{K}-$ $\mathrm{B}$ metasomatism, which raised the $\mathrm{K}_{2} \mathrm{O}$ contents up to $\sim 10 \mathrm{wt} \%$. The average $\mathrm{B}$ content of $218 \mu \mathrm{g} \mathrm{g}-1$ is well above the B content of common sediments, and the B-isotope composition reaches extremely low values of down to $-33 \% \circ \delta^{11} \mathrm{~B}$. The top of the sequence is a lazulite quartzite, interpreted as a former conglomeratic phosphatic sandstone, which marks the transition from a closed Permian basin to an open Triassic basin. Within the clastic sequence, the presence of hydrothermal tourmalinite veins documents a hydrothermal event after deposition but before the onset of Alpine metamorphism. A metamorphosed mafic dike swarm in the orthogneiss indicates a post-Variscan event of basaltic magmatism, and this event is tentatively correlated with increased heat flow in the Triassic basin and hydrothermal activity. A consistent conceptual model of this basin and its diagenetic modifications, based on a combination of geochemical data with petrographical and field information, provides the geodynamic context of the European margin at the onset of the Alpine orogeny.
\end{abstract}




\section{Introduction}

Paleogeographic reconstructions allow us to translate the modern rock record into a picture of Earth's dynamic past. The geochemistry of meta-igneous rocks is routinely used to decipher pre-orogenic origins, revealing the traces of former magmatic arcs, intrusions, or spreading centers (e.g., Middlemost, 1994; Pearce and Cann, 1973; Pearce et al., 1984). However, geochemical fingerprinting is less regularly applied to metasedimentary rocks. Reconstructing the depositional environment of these often-neglected strata can contribute important insights into puzzles needed to understand the greater paleogeodynamic picture. Here, we use the major and trace elements (including rare earth elements, REEs, plus $\mathrm{Y}$ ), as well as B contents and B-isotope chemical composition, of a metasedimentary unit and its basement to decipher the nature of the protoliths and their depositional environment. The area for this case study is a Permian-Mesozoic basin with predominantly continental clastic deposits, situated above a Variscan basement, located at the Pfitscher Joch (Passo di Vizze in Italian), on the Austrian-Italian border (Fig. 1). We show that despite a strong metamorphic overprint, geochemical data combined with detailed mapping (Lammerer, 1986) and petrographic descriptions (Veselá and Lammerer, 2008; Veselá et al., 2008, 2011), complemented by our own observations, allow derivation of a consistent picture of the sedimentary and diagenetic environments for the basin. This information provides the geodynamic context of the European margin at the onset of the Alpine orogeny.

\subsection{Regional geology}

The southwestern Tauern Window in the Eastern Alps is a classic area for investigating the interplay between tectonics and metamorphism of the Alps. This easily accessible area with excellent outcrops is also popular for field trips that capitalize on the perfectly exposed important features of the Eastern Alps (e.g., Morteani, 1974; Lammerer and Morteani, 1990; Lammerer et al., 2011). This tectonic window exposes part of the Subpenninic and Penninic units, which are otherwise hidden by the overthrusted Austroalpine superunit (Fig. 1).

The Pfitscher Joch area has been the focus of a particularly large amount of research aimed at reconstructing the pressure-temperature-time path of different tectonic units in the Tauern Window (Selverstone et al., 1984; Selverstone and Spear, 1985; Selverstone, 1988; Schulz et al., 1995; Schulz, 1996), their structural evolution (Selverstone, 1985, 1993), and age data using different isotope systems and minerals (e.g., Glodny et al., 2008; Schmid et al., 2013; Rosenberg et al., 2018; Ricchi et al., 2020, and references therein). This work has generated a coherent picture of regional metamorphic tectonic Alpine history. The peak of orogenic metamorphism reached temperatures of up to $500-550^{\circ} \mathrm{C}$ and pressures of up to 1.0-1.1 GPa (Selverstone et al., 1984). Nearly isothermal decompression was rapid (Selverstone et al., 1984) and occurred during orogen-parallel exhumation (e.g., Ratschbacher et al., 1991) and large-scale E-W extension (Behrmann, 1988; Selverstone, 1988).

The Subpenninic and Penninic units exposed by the Tauern Window have been interpreted as the pre-Alpine distal European margin and remnants of the Tethys Ocean, respectively (e.g., Schmid et al., 2013, and references therein). The post-Variscan metasedimentary units described herein (Fig. 1) belong to the Subpenninic nappes, exposed in the core of the Tauern Window. These strata are the stratigraphically lowermost tectonic units and primarily consist of (pre)Variscan basement rocks intruded by late- and post-Variscan granitoids and subvolcanic rocks (e.g., Cesare et al., 2002; Veselá et al., 2011). The latter units are traditionally referred to as the Zentralgneis ("gneiss cores", e.g., Morteani, 1974; "gneiss horsts", Veselá and Lammerer, 2008). In the western Tauern Window, the Zentralgneis is divided into the Ahorn, Tux, and Zillertal nappes, stacked to form the Venediger Duplex (e.g., Frisch, 1980; Lammerer and Weger, 1998; Lammerer et al., 2008; Schmid et al., 2013). The Tux Zentralgneis is characterized as a strongly fractionated, calc-alkaline, Itype granitoid (Finger et al., 1993); hosts the molybdenite deposit of the Alpeinerscharte; and shows features of intermediate argillic alteration (Mostler et al., 1982; Melcher et al., 1995), typical of porphyry granitoids.

The metasedimentary cover overlies the Tux and Zillertal units and is folded between these two rigid bodies into an elongated basin, the Pfitsch-Mörchner basin, together with other post-Variscan sedimentary basins. Veselá et al. (2008) and Veselá and Lammerer (2008) proposed post-Variscan intramontane basins as the depositional environment for the Carboniferous to Mesozoic sediments. Such basins would have formed part of a network of basins in the paleogeographical central European and Alpine region of Pangea, which Elter et al. (2020) described as comprising pull-apart basins between the landmasses of Laurussia and Gondwana.

Today, the metasedimentary rocks of the PfitschMörchner basin form a large, ENE-WSW-striking, isoclinally folded syncline that runs parallel to the Greiner shear zone, which is situated between the Tux and the Zillertal Zentralgneis units (e.g., Behrmann, 1988; Behrmann and Frisch, 1990; Selverstone et al., 1991), together with the Ahorn, Olperer, and Tux shear zones (e.g., Rosenberg and Schneider, 2008; Ricci et al., 2020). The original bedding is apparent in lithologic contacts, except near to the fold hinge where shearing has obliterated the original sedimentary structure. The Carboniferous to Jurassic age (Veselá et al., 2011) of the major basins of the western Tauern Window limits these post-Variscan cover units to having experienced only Alpine greenschist to amphibolite facies metamorphism. Any indications of Permian low-temperature hydrothermal metamor- 


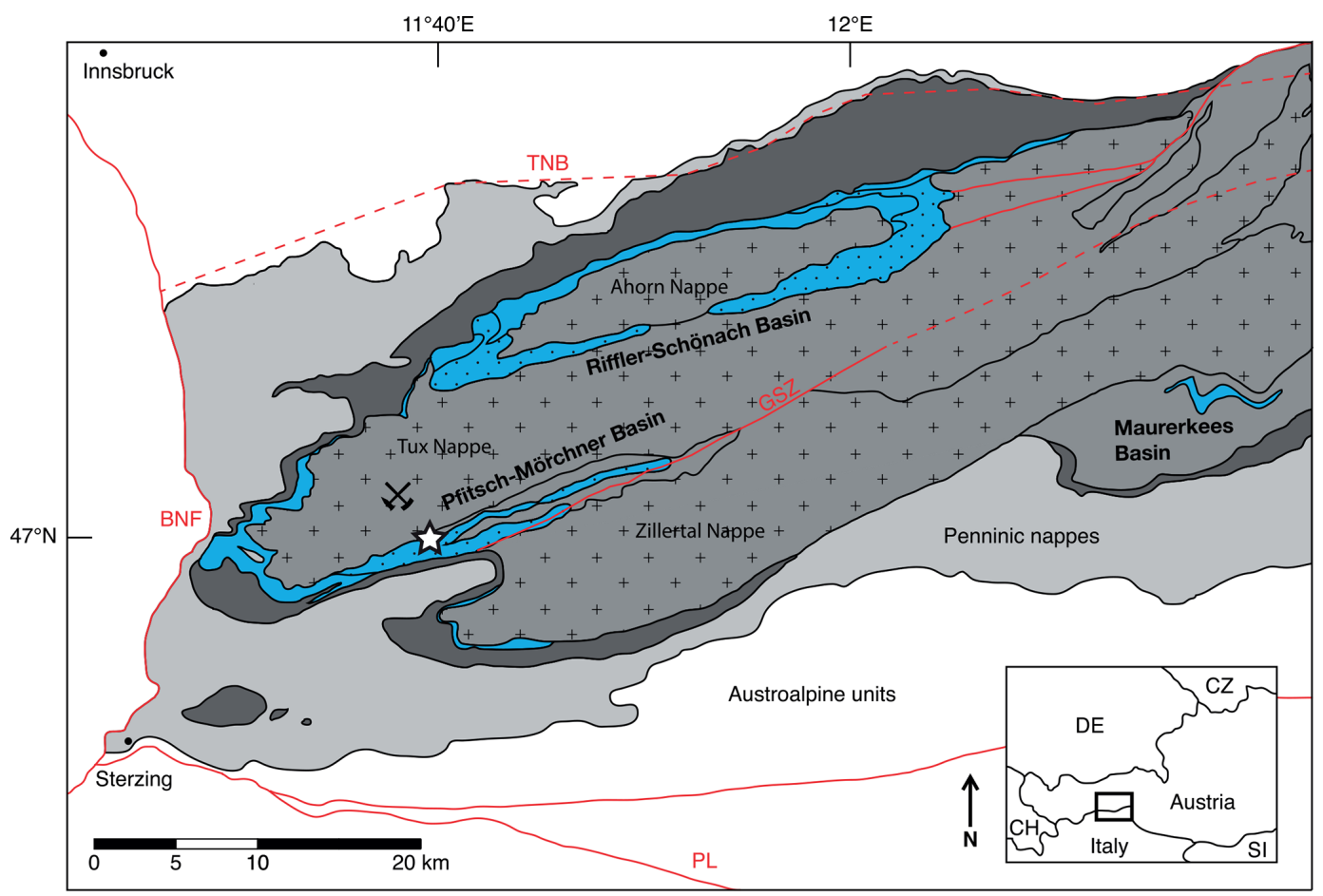

Post-Variscan metasedimentary basins in the Western Tauern Window:

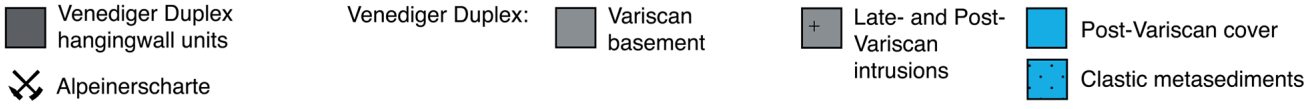

Figure 1. Geological sketch map of the western Tauern Window (inset shows the location at the Italian-Austrian border), highlighting the post-Variscan metasedimentary basins. Star indicates position of the schematic sedimentary profiles (Fig. 2), and the mine symbol indicates "Alpeinerscharte", the location of the abandoned molybdenite mine. Modified from Lammerer et al. (2008) and Veselá et al. (2008). Abbreviations: TNB, Tauern North Boundary Fault; BNF, Brenner Normal Fault; PL, Pustertal Line, part of the Periadriatic Lineament; GSZ, Greiner shear zone.

phism found in other parts of the Alps (review in Schuster and Stüwe, 2008) have probably been erased by the stronger Alpine metamorphism.

\subsection{Petrography of the Pfitsch-Mörchner basin and sample material}

The sample set is subdivided into the SE limb and the NW limb of the fold (Fig. 2). It comprises basement rocks and the overlying metasedimentary rocks, including what Veselá and Lammerer (2008) called the Pfitsch Formation and the Windtal Formation, up to an overlying marble unit, the Aigerbach Formation. The geological map of the Brenner Basistunnel 1:50000 (Brandner et al., 2011) classifies the sequence as the Triassic Aigerbach Formation overlying Permian(?) metaconglomerates. In the compilation of Schmidt et al. (2013) the sequence corresponds to their units 1 and 2 (basement), 4 (conglomerates), 5 (Permo-Scythian quartzites), and 6 (limestone).

Beneath the SE limb of the fold, the basement consists of thin $(<100 \mathrm{~m})$ orthogneiss lamella of the Zillertal Zentralgneis, amphibolite (variety hornblende garbenschist), and small bodies of serpentinite (Fig. 2). Further south lies a thick (pre-)Variscan series of graphitic mica schists called Furtschagl schist (Christa, 1931; Selverstone and Muñoz, 1987). Northward, the uppermost unit of the SE limb is a quartzite, separated from the metasedimentary sequence by a 1-2 $\mathrm{m}$ thin layer of hornblende garbenschist (see Supplement 4.3.4 in Franz et al., 2021). It marks the top of the basement, characterized by a conspicuous reddish weathering of pyrite from which the local name of the Rotbachl ("red creek") is derived, best exposed in a profile at the crest of the Rotbachlspitze (Fig. 3a). This pyrite quartzite has a welldeveloped schistosity with some white mica. It is feldsparalbite)-bearing in several layers near the base, where it is interspersed with a biotite-chlorite-plagioclase gneiss. It also has a zone rich in quartz and kyanite and a smaller lens rich in staurolite, in addition to several quartz segregations. Near the top, magnetite-rich lenses appear. These lenses extend up to $30 \mathrm{~m}$ along strike and a few meters perpendicularly to strike; the assemblage contains magnetite-chloritoidstaurolite-chlorite-ilmenite-white mica-quartz, locally with 


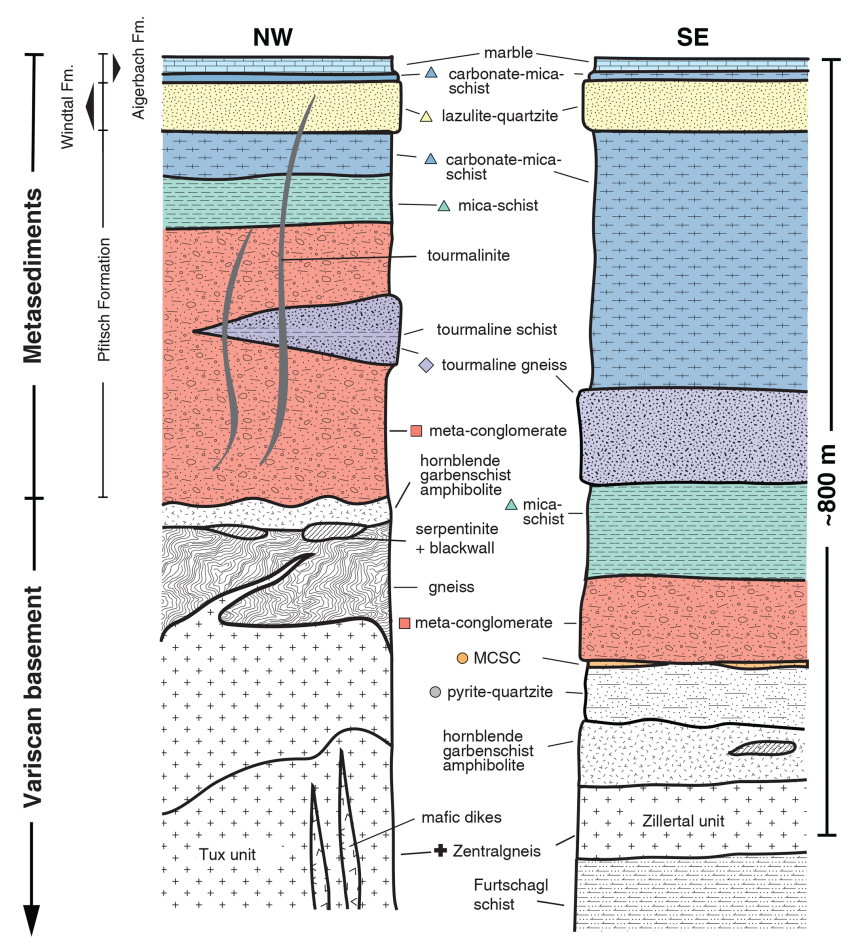

Figure 2. Schematic stratigraphic columns of the rocks from the Pfitsch-Mörchner basin, reconstructed from Lammerer (1986), Veselá and Lammerer (2008), and own mapping. Shown is the situation on the NW and SW limb of the syncline near to the road to the Pfitscher Joch as it might have appeared after sedimentation, neglecting Alpine deformation (e.g., the originally crosscutting tourmalinite dike in the NW limb is isoclinally folded and oriented parallel to strike). Note that along-strike thickness of the units varies; e.g., the pyrite quartzite in the SE limb is much thicker at Rotbachlspitze, and it pinches out towards the SW and NE.

albite, in varying proportions (Fig. 3c; Barrientos and Selverstone, 1987), abbreviated below as MCSC lenses.

The metasedimentary succession of the Pfitsch-Mörchner basin starts with a strongly sheared metaconglomerate (Fig. 3d). Up-section the metaconglomerate grades into a thin layer of mica schist, followed by $\sim 30 \mathrm{~m}$ of a tourmaline-rich, poorly foliated feldspathic rock called tourmaline gneiss (Berryman et al., 2017). The high tourmaline content, which was formed during metamorphism, is a characteristic feature of these rocks, and tourmaline also occurs in segregations. The gneiss contains lenticular quartz- and feldspar-rich, mica- and chlorite-poor bodies, up to $5 \mathrm{~cm}$ long and up to $1.5 \mathrm{~cm}$ thick, interpreted as relict pebble structures (Fig. 3e; for more images see Supplement 4.3.8 in Franz et al., 2021). In some areas, $\sim 20 \mathrm{~cm}$ thick lenses of fine-grained, muscovite-bearing quartzite appear between the tourmaline gneiss and layers of mica schist (with chlorite and biotite). In sharp contact with the latter is a fine-grained, chloritebiotite schist grading upwards into biotite schist, grouped here together and subsequently referred to as mica schist.
The Pfitsch-Mörchner basin succession is topped by an approximately $250 \mathrm{~m}$ thick unit of carbonate-mica schist distinguished in the field by ankerite-biotite aggregates (sites for the reaction ankerite + muscovite $=$ calcite + biotite). The same unit is only $\sim 50 \mathrm{~m}$ thick in the NW limb of the basin.

In the NW limb, the basement (Fig. 2) is formed by the large Tux Zentralgneis body that consists of several intrusions of granitoids with aplite dikes. In the investigated area, we distinguish two types: one with the local name "Augenflasergneis" (describing the augen texture and irregular foliation) and a leucocratic type with a poorly developed foliation that is referred to here as "Schrammacher Gneis" (interpreted as a highly differentiated granite with local beryl-phenakite mineralization; Franz et al., 1986). The granitoids are cut by post-Variscan mafic dikes, which were transformed into biotite schist during Alpine metamorphism (Fig. 3b). The host rocks of the granitoids, known as "Altes Dach" (old roof pendant), are predominantly amphibolites with minor amounts of garnet-bearing (para)gneiss, hornblende garbenschist, and a series of serpentinite bodies with blackwall zoning. A pyritic quartzite unit with MCSC lenses corresponding to that identified at the top of the basement units in the SE limb could not be identified. The succession of the Pfitsch Formation starts with a poorly sorted metaconglomerate and in places a meta-breccia, well exposed at a small lake (Langsee; De Vecchi and Baggio, 1982; Lammerer, 1986). The large pebbles (Fig. 3d) are up to $30 \mathrm{~cm}$ in size; angular to sub-rounded; and made of macroscopically distinguishable gneisses (meta-aplite, biotite-bearing metagranite), calc-silicates (rich in epidote minerals), amphibolite, marble, biotite schist, mica schist with Cr-bearing muscovite, and quartz in a fine-grained matrix of mica-chloriteplagioclase-epidote-quartz. The mica schist with Cr-bearing muscovite (Lammerer, 1986; Schön and Lammerer, 1993) is a characteristic pebble type and guides identification of the metaconglomerate unit in areas of high strain, where the shape of the pebbles has been obliterated by Alpine shearing and flattening. This is especially the case in the SE limb, where these rocks show a well-developed schistosity defined by white mica and small-scale layering. In the NW limb, the metaconglomerate crops out over approximately $200 \mathrm{~m}$, and in the SE limb it crops out over approximately $100 \mathrm{~m}$. Lammerer (1986) estimated the original thickness of the unit as nearly $500 \mathrm{~m}$.

The contact between the Pfitsch Formation and the next unit (Windtal Formation), a muscovite-bearing lazulite quartzite with a well-developed schistosity, is gradual over a distance of approximately $2 \mathrm{~m}$. This contact zone has thin layers (centimeters to tens of centimeters) of carbonatemica schist alternating with muscovite-bearing quartzite. The quartzite contains conspicuous blue lazulite (Fig. 3f), together with kyanite, staurolite, magnetite, hematite, chlorite, tourmaline, and a number of different Al-P minerals (lazulite, svanbergite-goyazite, bearthite, apatite), described in detail in Morteani and Ackermand (1996). Staurolite oc- 

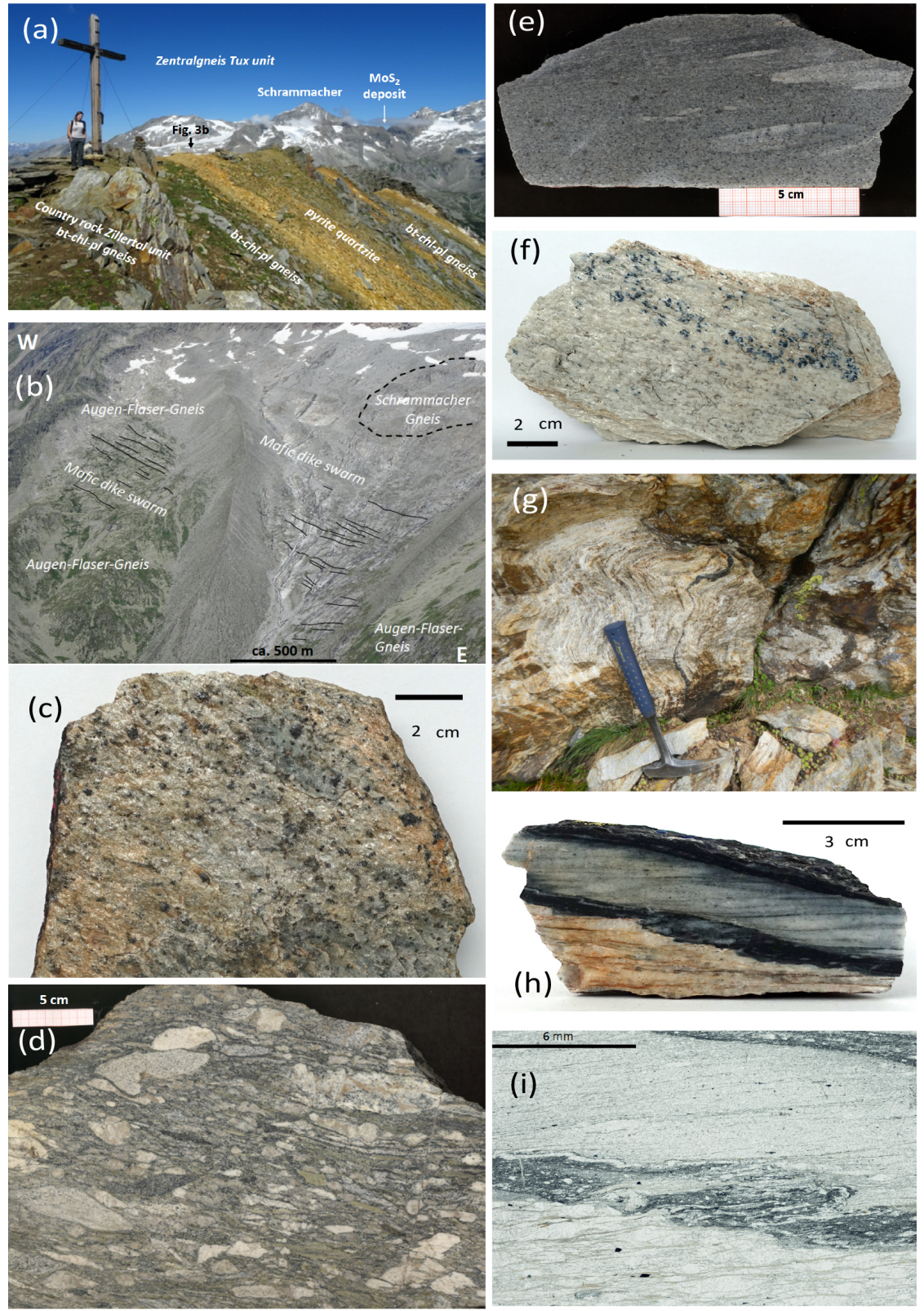

Figure 3. Field photographs and hand specimen and thin-section images of representative rocks. (a) View at top of Rotbachlspitze, showing in the foreground the basement of the Pfitsch-Mörchner basin, the Zillertal unit country rock (biotite-chlorite-plagioclase gneiss), interlayered with weathered reddish pyrite quartzite. The background shows the peaks of the Zentralgneis from the Tux unit, with the Schrammacher peak and to its right the locality of the molybdenite deposit of the Alpeinerscharte. Location of the figure (b) with the mafic dike swarm is indicated. (b) View from the crest of the Rotbachlspitze towards the lower part of the Tux Zentralgneis, with the mafic dike swarm (outlined) between and left of the two moraine walls of the Schrammacher glacier. (c) Hand specimen of magnetite-chloritoid-staurolite-chlorite lens; sample is $12 \mathrm{~cm}$ wide. The specimen is similar to sample $\mathrm{H}$ in Barrientos and Selverstone (1993). (d) Cut slice of metaconglomerate, the base of the Mesozoic Pfitsch-Mörchner basin. Note partly angular, partly rounded pebble components (for more details, see text). (e) Cut and polished slice of tourmaline gneiss with light, lens-shaped, feldspar-rich aggregates, interpreted as deformed pebbles of a conglomeratic precursor (for more photos see Supplement 4.3.8 in Franz et al., 2021) (f) Hand specimen of lazulite quartzite, the top of the PfitschMörchner Formation, view onto the foliation plane; size of the sample's longest dimension is $16 \mathrm{~cm}$. Light blue patches are aggregates of lazulite with other phosphate minerals (for details, see text). (g) Field photograph of strongly deformed and folded metaconglomerate, with a thin tourmalinite vein (upper right of hammer handle). (h) Cut and polished slice of tourmalinite vein in the lazulite quartzite. Foliation is horizontal; the vein is slightly discordant to the weathered yellowish quartzite. Note the bimodal character of the tourmalinite, with an upper and lower domain rich in tourmaline and a quartz-rich central domain; for more photos of crosscutting relations see Supplement 4.3.6 in Franz et al. (2021) and Henry et al. (2002). (i) Thin-section micrograph of hand specimen (plane-polarized light), shown in (g), showing the central fine-grained and quartz-rich domain (upper part), followed by the tourmaline-rich domain. The lower part is the conglomeratic quartzite country rock. 
curs only in the SE limb and is not observed in samples with lazulite. Heavy minerals are concentrated in layers, suggesting the original bedding (Morteani and Ackermand, 1996). The high content of quartz indicates a compositionally mature sandstone protolith. Magnetite ( \pm chlorite) dominates in the NW limb. Flattened quartz nodules, up to approximately $10 \mathrm{~cm}$ in length, record dominantly plane strain and are sites of major volume loss by pressure solution (Selverstone and Hyatt, 2003).

Quartz veins and tourmalinite veins, $\sim 1-2 \mathrm{~cm}$ thick, consisting of quartz and very fine grained tourmaline, cut the lazulite quartzite (Henry et al., 2002; Selverstone and Hyatt, 2003). Tourmaline-rich and quartz-rich domains comprise the tourmalinite veins (Fig. $3 g$, h). Tourmaline-rich bands contain up to $75 \mathrm{vol} \%$ tourmaline, and quartz-rich bands contain $<10$ vol \% tourmaline (Fig. 3i; Henry et al., 2002). In places where they cut the original bedding, the veins are isoclinally folded (Fig. 3g); in other areas, the veins are (sub)parallel to the foliation (Fig. 3h). In some occurrences, the veins are dismembered by shearing and resemble centimeter-sized pebbles (Lammerer, 1986); for more images see Supplement 4.3.6 in Franz et al. (2021) and Henry et al. (2002). These relicts of the tourmalinite veins were also found in the metaconglomerate and in the tourmaline gneiss.

The uppermost metasedimentary unit in this area is a dolomite marble (Aigerbach Formation; Veselá and Lammerer, 2008), which forms the central part of the fold.

\section{Geochemical results}

Whole-rock major and trace elements (205 samples) were determined by X-ray fluorescence at Technische Universität Berlin, except REEs, which were determined on a subset of 23 samples by ICP-MS on fused samples at Actlabs in Vancouver, Canada (code 4B2). Boron concentrations and isotope ratios of 25 whole-rock samples were analyzed in the Isotope Geochemistry Laboratory at MARUM - Center for Marine Environmental Sciences, University of Bremen (Germany).

The complete dataset of the different units - metasediments and basement (14 samples for the metaconglomerate unit, 19 for the mica schist, 9 for the carbonate-mica schist, 35 for the tourmaline gneiss, 25 for the lazulite quartzite, 1 for the marble, 39 for the Zentralgneis, 9 for biotitechlorite-plagioclase gneiss, 31 for the pyrite quartzite, 9 for the MCSC lenses, and 11 for serpentinite including blackwall zones) - is published in a data repository at https://doi.org/10.5880/fidgeo.2021.013 (Franz et al., 2021) and presented in Fig. 4, together with data from previous studies (Barrientos and Selverstone, 1987; Morteani and Ackermand, 1996; Selverstone and Hyatt, 2003; Berryman et al., 2017). The very heterogeneous pre-Variscan gneissamphibolite unit and the Furtschagl schist were not analyzed for major- and trace-element composition, but B contents and B-isotope compositions were determined.

\subsection{Major and trace elements}

Overall, the metasedimentary rocks have a wide range of $\mathrm{Al}_{2} \mathrm{O}_{3}$ and $\mathrm{SiO}_{2}$ contents (Fig. 4a), whereas the orthogneisses (Zentralgneis) show a restricted $\mathrm{SiO}_{2}$ content between $\sim 70$ and $\sim 78 \mathrm{wt} \%$. Data from the serpentinite bodies include metasomatically altered border zones (blackwall zones of talc, actinolite, chlorite, biotite; similar to rocks described by Trumbull et al., 2008, from the Tauern Window east of the study area), which are high in $\mathrm{Al}_{2} \mathrm{O}_{3}$ and $\mathrm{K}_{2} \mathrm{O}$. Most data from the MCSC lenses have > $20 \mathrm{wt} \% \mathrm{Al}_{2} \mathrm{O}_{3}$, but there is a significant overlap with data from the pyrite quartzite. The lazulite quartzite has $\mathrm{SiO}_{2}$ contents up to 90 wt \%; samples with high $\mathrm{Al}_{2} \mathrm{O}_{3}$ contents (>25 wt \%) are mica-rich selvages around quartz nodules, indicative of silica loss during Alpine deformation (Selverstone and Hyatt, 2003).

Mica schist, carbonate-mica schist, and tourmaline gneiss follow a common positively correlated trend in $\mathrm{MgO}$ and

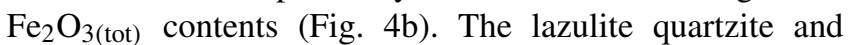
MCSC lenses, corresponding to the top and bottom of the Pfitsch Formation, respectively, both have high $\mathrm{Fe}_{2} \mathrm{O}_{3}$ (tot) and relatively low $\mathrm{MgO}$. In contrast, the pyrite quartzite that surrounds and underlies the MCSC lenses has a low $\mathrm{Fe}_{2} \mathrm{O}_{3 \text { (tot) }}$ content and a relatively high $\mathrm{MgO}$ content. Alkali elements $\mathrm{Na}_{2} \mathrm{O}$ and $\mathrm{K}_{2} \mathrm{O}$ (Fig. 4c) of metaconglomerate, tourmaline gneiss, and mica schists show a negative correlation, the lazulite quartzite and the pyrite quartzite being very poor in $\mathrm{Na}_{2} \mathrm{O}$, except the feldspar-bearing variety of the pyrite quartzite. In terms of $\mathrm{CaO}$ and $\mathrm{Na}_{2} \mathrm{O}$ (not shown), the mica schist, carbonate-mica schist, and tourmaline gneiss are Ca-dominant, whereas many samples of the metaconglomerate, MCSC lenses, and pyrite quartzite are Na-dominant. The $\mathrm{Ca}$ contents are variable and reach $10 \mathrm{wt} \% \mathrm{CaO}$ in the tourmaline gneiss and $17 \mathrm{wt} \% \mathrm{CaO}$ in one metaconglomerate sample. The carbonate-mica schist $(3.75 \mathrm{wt} \% \mathrm{CaO})$ and mica schist (3.05 wt \% CaO) do not differ significantly.

The $\mathrm{K}_{2} \mathrm{O}$ and $\mathrm{Rb}$ contents are well correlated (Fig. 4d), forming two trends: one for the tourmaline gneiss, carbonate-mica schist, and mica schist and the other for the lazulite quartzite, MCSC lenses, and the pyrite quartzite. Values for the heterogeneous metaconglomerate scatter strongly and are not included in these trend lines. The first trend corresponds to an $\mathrm{Rb} / \mathrm{K}$ ratio in the range of $\sim 0.003$ to 0.008 , centering around a value of $0.005\left(R^{2}=0.79\right)$. This trend is consistent with the average $\mathrm{K}_{2} \mathrm{O}$ and $\mathrm{Rb}$ values for clastic sediments from upper continental crust (sandstone and shale; Turekian and Wedepohl, 1961). The orthogneisses (variety Augenflasergneis and gneiss from the Zillertal unit) show a comparable trend; data for the Schrammacher Gneis similarly display a large amount of scatter $\left(R^{2}=0.65\right)$. Lazulite quartzite, MCSC lenses, and pyrite quartzite trend closely 

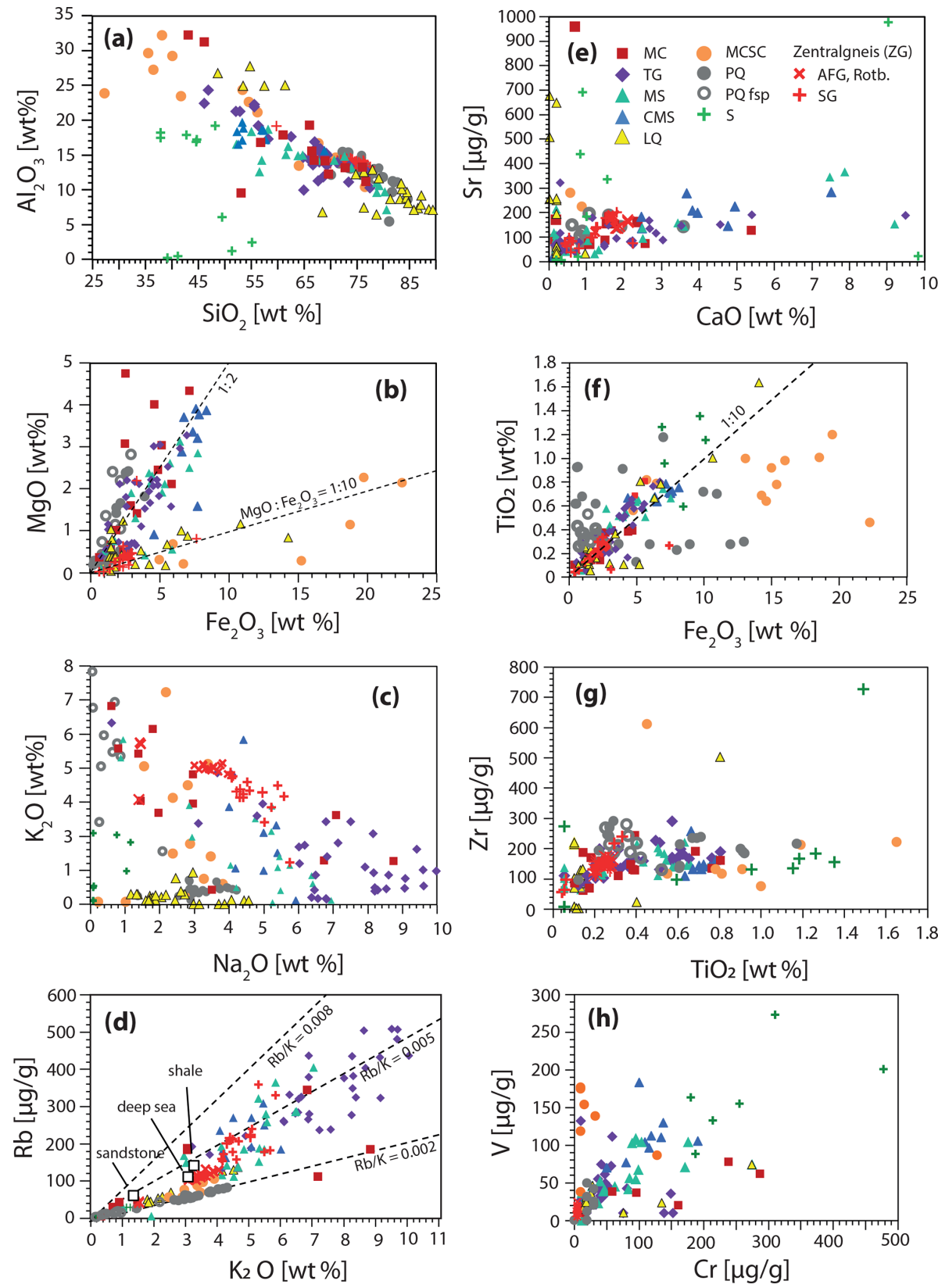

Figure 4. Variation diagrams illustrating the chemical composition of rock units from the Pfitsch area. Data are presented in the data publication (Franz et al., 2021) and include data from the literature and this work. (a) $\mathrm{SiO}_{2}-\mathrm{Al}_{2} \mathrm{O}_{3}$; the metasedimentary rock units show a large spread, e.g., tourmaline gneiss ranges from approximately $45 \mathrm{wt} \% \mathrm{SiO}_{2}$ to $77 \mathrm{wt} \% \mathrm{SiO}_{2}$ and mica schist and carbonate-mica schist from approximately $52 \mathrm{wt} \%$ to $80 \mathrm{wt} \% \mathrm{SiO}_{2}$. Data points for lazulite quartzite with $>25 \mathrm{wt} \% \mathrm{Al}_{2} \mathrm{O}_{3}$ represent mica-rich selvages around quartz nodules and indicate local transport of $\mathrm{SiO}_{2}$ (Selverstone and Hyatt, 2003); data points for serpentinite with $>17 \mathrm{wt} \% \mathrm{Al}_{2} \mathrm{O}_{3} \mathrm{represent}$ biotite-chlorite-rich blackwall zoning, indicating local metasomatism. The Zentralgneis shows a very restricted composition (one outlier at $60 \mathrm{wt} \% \mathrm{SiO}_{2}$ represents a biotite-rich zone). (b) $\mathrm{MgO}-\mathrm{Fe}_{2} \mathrm{O}_{3}$; metasediments follow a broad $1: 2$ correlation. The MCSC lenses and the lazulite quartzite are significantly enriched in $\mathrm{Fe}_{2} \mathrm{O}_{3}$, the pyrite quartzite and the feldspar-bearing pyrite quartzite are enriched in $\mathrm{MgO}$. (c) $\mathrm{Na}_{2} \mathrm{O}-\mathrm{K}_{2} \mathrm{O}$; tourmaline gneiss shows high but variable $\mathrm{K}_{2} \mathrm{O}$ contents, and lazulite quartzite is poor in $\mathrm{Na}_{2} \mathrm{O}$. (d) $\mathrm{Rb}-\mathrm{K}_{2} \mathrm{O}$; trace element $\mathrm{Rb}$ is closely coupled to $\mathrm{K}$. The tourmaline gneiss, mica schist and carbonate-mica schist follow a trend of $\mathrm{Rb} / \mathrm{K}=0.005$, close to the trend defined by average composition of shale and sandstone (from Turekian and Wedepohl, 1961), but with a large variation between 0.008 and 0.002 . The Zentralgneis variety AFG (Tux branch) and Zillertal branch (Rotbachlspitze) are well correlated, whereas the variety Schrammacher Gneis (SG) shows a large spread. The pyrite quartzite has the lowest $\mathrm{Rb} / \mathrm{K}$ at below 0.002. (e) $\mathrm{Sr}-\mathrm{CaO}$; although $\mathrm{Sr}$ is broadly coupled to $\mathrm{Ca}$, there are extreme Sr enrichments in samples of the lazulite quartzite (inset), due to celestite in some samples (Morteani and Ackermand, 1996). (f) $\mathrm{TiO}_{2}$ and $\mathrm{Fe}_{2} \mathrm{O}_{3}$ (total) are positively correlated near to a value of $1: 10$, although with a large scatter; the paleosol has high $\mathrm{Fe}_{2} \mathrm{O}_{3}$ contents. Lazulite quartzite samples with high $\mathrm{TiO}_{2} / \mathrm{Fe}_{2} \mathrm{O}_{3}$ values represent mica-rich selvages around quartz (Selverstone and Hyatt, 2003). 


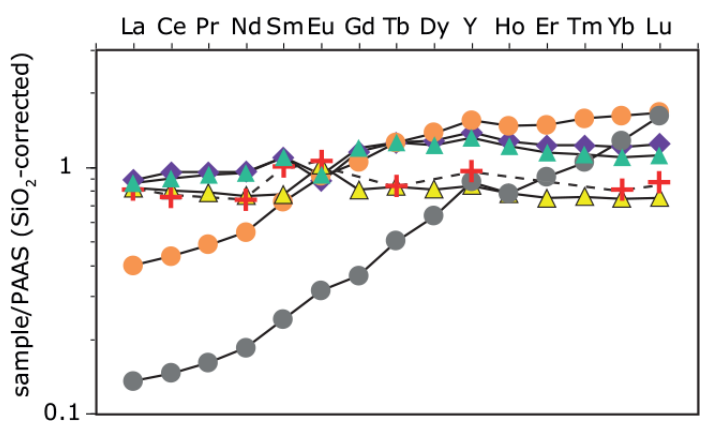

Figure 5. $\mathrm{REE}(+\mathrm{Y})$ distribution pattern of averages of samples from the Pfitsch area; abbreviations are as follows: LQ is lazulite quartzite; ZG is Zentralgneis (data from Finger et al., 1993); MS is mica schist; TG is tourmaline gneiss; PQ is pyrite quartzite; MCSC is magnetite-chloritoid-staurolite-chlorite lens. Normalization to post-Archean Australian shale (PAAS) composition (normalization values from Pourmand et al., 2012). Due to the very high quartz content of several samples, all values were corrected for $\mathrm{SiO}_{2}$ content (see text).

near an average of $0.002 \mathrm{Rb} / \mathrm{K}$, suggesting fractionation of $\mathrm{Rb}$ from $\mathrm{K}\left(R^{2}=0.84\right)$.

Strontium and Ca contents (Fig. 4e) are extremely variable and poorly correlated. The lazulite quartzite, despite having a very low $\mathrm{Ca}$ content, is strongly enriched in $\mathrm{Sr}$, up to $20000 \mathrm{\mu g} \mathrm{g}^{-1}$, and contains accessory celestite (see Morteani and Ackermand, 1996). Serpentinite rocks with blackwall zoning also show high $\mathrm{Sr}$ values of up to $700 \mu \mathrm{g} \mathrm{g}^{-1}$ in several samples. A similarly strong heterogeneity is observed for $\mathrm{Ba}$ (not shown), which can reach $>20000 \mu \mathrm{g} \mathrm{g}^{-1}$ in samples of the metaconglomerate, indicating local enrichment of a Ba mineral, likely baryte. In the case of the MCSC lenses and the metasedimentary rock, no correlation exists between $\mathrm{Sr}$ and $\mathrm{Ba}$. Whereas the behavior of $\mathrm{Rb}$ was observed to be largely controlled by the behavior of $\mathrm{K}$, $\mathrm{Sr}$ is only poorly correlated with $\mathrm{Ca}$ in both the metasedimentary rocks (trend line with $\left.R^{2}=0.46\right)$ and the orthogneiss $\left(R^{2}=0.55\right)$.

The high-field-strength elements (HFSEs) Ti, Nb, and Zr, assumed to be less fluid-mobile and hosted in the sediments predominantly by heavy minerals (e.g., rutile-anatasebrookite, ilmenite, and zircon), are poorly correlated with $\mathrm{Fe}_{2} \mathrm{O}_{3 \text { (tot) }}$ (Fig. 4f, g; Nb not shown). Contents of $\mathrm{Zr}$ and Ti reflect the amounts of detrital zircon and ilmenite, which are scattered and also reflect maturity of the precursor sediments. However, $\mathrm{TiO}_{2}$ is broadly correlated with $\mathrm{Fe}_{2} \mathrm{O}_{3}$ (tot) in all samples, with the exception of the lazulite quartzite and the pyrite quartzite. The $\sim 1: 10 \mathrm{TiO}_{2}: \mathrm{Fe}_{2} \mathrm{O}_{3}$ (tot) trend likely reflects the relative abundance of primary ilmenite/Ti magnetite inherited from the sediment source (Fig. 4g). Good correlation in the orthogneiss records the preservation of a magmatic fractionation trend, since the low fluid mobility of these elements implies limited movement during metamorphism.
Elevated concentrations of the trace elements $\mathrm{Cr}, \mathrm{V}$, (Fig. 4h) and $\mathrm{Ni}$ (not shown) in sediments can be considered a signature of an ultramafic-mafic source rock, such as the serpentinites. Chromium (and $\mathrm{Ni}$ ) reaches its highest values of up to $300 \mathrm{\mu g} \mathrm{g}^{-1}$ in the metaconglomerate and in the lazulite quartzite. In the tourmaline gneiss, carbonatemica schist, and mica schist, these elements are generally positively correlated, with some samples showing local enrichment in either $\mathrm{V}$ or $\mathrm{Cr}$. Within the siliciclastic rocks of the Pfitsch Formation, the tourmaline gneiss has low $\mathrm{Cr}$ (15 to $150 \mu \mathrm{g} \mathrm{g}^{-1}$ ), $\mathrm{V}$ (15 to $130 \mu \mathrm{g} \mathrm{g}^{-1}$ ), and $\mathrm{Ni}$ (up to $40 \mu \mathrm{g} \mathrm{g}^{-1}$ ) contents, but these are still much higher than in the orthogneiss, which has values near or below the detection limit of $\sim 0.10 \mathrm{\mu g} \mathrm{g}^{-1}$ in most samples. Most samples of the MCSC lenses are enriched in V.

Average $\mathrm{REE}(+\mathrm{Y})$ patterns of the different rock units are shown normalized to post-Archean Australian shale (PAAS; Fig. 5). The individual patterns for the metasedimentary rocks differ mainly in terms of absolute REE contents, due to the fact that quartz (with negligible REE content) varies greatly in abundance in many samples. To account for this, we corrected all average REE values by a factor $f=\mathrm{wt} \% \mathrm{SiO}_{2}^{\text {sample }} / \mathrm{wt} \% \mathrm{SiO}_{2}^{\text {PAAS }}$. No REEs were determined for the highly heterogeneous metaconglomerates. The data for the mica schist exclude a quartz-rich sample (no. 2814) with strong enrichment of the middle to heavy REEs and a pronounced negative Eu anomaly. The reason for this unusual pattern in this particular sample is its atypical enrichment of xenotime, determined by X-ray mapping of the thin section (see Supplement 4.3.5 in Franz et al., 2021). In some cases, individual patterns have different ratios of light to heavy REEs, because the REE budget of the precursor sediments is controlled mainly by the amount and type of heavy mineral, such as monazite (light REE-bearing), xenotime (heavy REE-Y-bearing), and zircon.

There are no $\mathrm{Ce}$ anomalies in any of the analyzed rocks, suggesting a common oxidation state in the sediments. The mica schist and tourmaline gneiss patterns are flat, having abundance levels of ca. 1 for the light REEs, including $\mathrm{Eu}$, which has a slightly negative Eu anomaly $(\mathrm{Eu}-(\mathrm{Sm}+\mathrm{Gd}) / 2)$ of -0.2 . The middle to heavy REEs are slightly enriched. The orthogneiss, representing the inferred proximal source area, has a flat pattern, with total abundances slightly below that of PAAS, except for Sm and Eu that are both close to 1 . The lazulite quartzite shows a similar pattern to that of the Zentralgneis, with total abundances below those of PAAS and with a slightly positive Eu anomaly of 0.2 . The MCSC lenses and pyrite quartzite both display steep REE patterns, depleted in light REEs with REE contents increasing towards $\mathrm{Lu}$. The pyrite quartzite REE contents are consistently lower than the MCSC lenses, except for Lu. In chondrite-normalized patterns (see Supplement 4.3.9 in Franz et al., 2021) all units show a negative Eu anomaly, in line with the fact that the Zentralgneis is one of the dominant 


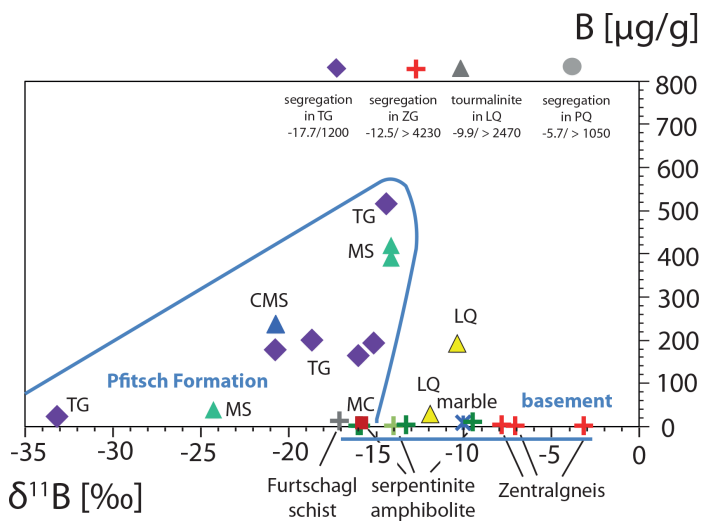

Figure 6. Whole-rock B contents and $\delta^{11} \mathrm{~B}$-isotope values of samples from the Pfitsch area. Zentralgneis, amphibolite, serpentinite, Furtschagl schist, and pyrite quartzite (PQ) are samples from the basement. The blue line limits the field of samples from the Pfitsch Formation. The tourmaline gneiss (TG) has the lowest $\delta^{11} \mathrm{~B}$-isotope value, but mica schist (MS) and carbonate-mica schist (CMS) also show low values. The lazulite quartzite (LQ) and the tourmalinite veins show values near to the basement rocks, as well as the overlying marble. The high B contents of the segregations and the tourmalinite outside the diagram are dominated by the modal amount of tourmaline mixed with quartz, and the variation has no petrogenetic significance.

sources, most prominent in the REE similarity to the lazulite quartzite and the Zentralgneis.

\subsection{Boron contents and $B$ isotopes}

The $\mathrm{B}$ contents and whole-rock $\delta^{11} \mathrm{~B}$ values are shown in Fig. 6 (for data see Franz et al., 2021). Average B contents in the Pfitsch Formation (combined data for the tourmaline gneiss, mica schist, and carbonate-mica schist) are $215 \mu \mathrm{g} \mathrm{g}^{-1}$; they are near $30 \mu \mathrm{g} \mathrm{g}^{-1}$ in the lazulite quartzite (Windtal Formation) and $4 \mu \mathrm{g} \mathrm{g}^{-1}$ in marble from the Aigerbach Formation. In contrast, the basement rocks (Zentralgneis, amphibolite, and serpentinite from the roof pendant Altes Dach and Furtschagl schist) all contain $\leq 14 \mu \mathrm{g} \mathrm{g}^{-1}$ of B (average $5.0 \mu \mathrm{g} \mathrm{g}^{-1}$ ). The B-isotope compositions vary widely, ranging from ca. -33 to $-3 \% \circ \delta^{11} \mathrm{~B}$, with the siliciclastic metasedimentary rocks of the Pfitsch Formation having values below ca. $-14 \% o \delta^{11} \mathrm{~B}$. Values for the lazulite quartzite and its associated tourmalinite veins are restricted to -9 to $-12 \%$ o $\delta^{11} \mathrm{~B}$, similar to those of the overlying marble. In most of the basement rocks (including a tourmalinebearing quartz-feldspar segregation), $\delta^{11} \mathrm{~B}$ tends towards more positive values with the lowest value of $-17 \% \circ \delta^{11} \mathrm{~B}$ measured in the Furtschagl schist.

\section{Discussion}

\subsection{Inferences about the protoliths}

The protolith of metamorphic rocks can be constrained by the geochemical fingerprint imparted by the sedimentary, metamorphic, or igneous precursor. To be able to infer the sedimentary protoliths of the Pfitsch Formation, our initial assumption is that the present metasedimentary rocks retain some signature of the original sedimentary compositions. The composition of the sedimentary precursor itself was altered from that of the hinterland rocks through several processes, which began during chemical weathering, continued during sediment mixing and transport along rivers and sorting during sediment deposition, and ended with porewater interaction and diagenesis.

During regional metamorphism, deviation from isochemical deformation results from element transport by metamorphic fluids and metamorphic differentiation. In our study area, metasomatism and element mobility on a small scale are evident in certain rock samples, such as the selvages surrounding quartz nodules in the lazulite quartzite (Selverstone and Hyatt, 2003), or on the scale of tens of centimeters from rock to segregation as shown in the tourmaline gneiss (Berryman et al., 2017). Blackwall zones around serpentinite bodies (Trumbull et al., 2009) are another example of strong metasomatism in the area. Large-scale fluid movement that significantly changes the bulk composition is typically expressed in channels (e.g., Ague, 2011, and references therein). For instance, in the SW Tauern Window, the Greiner shear zone channelized fluids into a narrow zone $2-10 \mathrm{~m}$ in width (Selverstone et al., 1991), distinguished in the field by a macroscopically visible change in mineralogy and fabric. Although the Greiner shear zone extends into the Pfitscher Joch area (Fig. 1), channelized fluid flow is not observed except in the hornblende garbenschist (Selverstone et al., 1984; Steffen et al., 2001; Steffen and Selverstone, 2006). Within these basement rocks, deformation was locally responsible for fluid access and chemical alteration but did not pervasively change the chemical composition of the rock unit. Moreover, even in the case of the high-pressure rocks of the Tauern Window, fluid heterogeneities between rock layers on the millimeter-to centimeter scale have been observed to persist during metamorphism (Selverstone et al., 1992). Taken together, these observations support our assumption that during regional, near-peak, and post-peak Alpine metamorphism - except for the transition from diagenesis to low-grade metamorphism - pervasive fluid movement and associated element mobility were limited, leaving the whole-rock composition of the metasedimentary rocks largely intact. In addition, the use of a large dataset from each rock series in our investigation allows the average element values to cancel out the chemical signature of small-scale element mobility. 

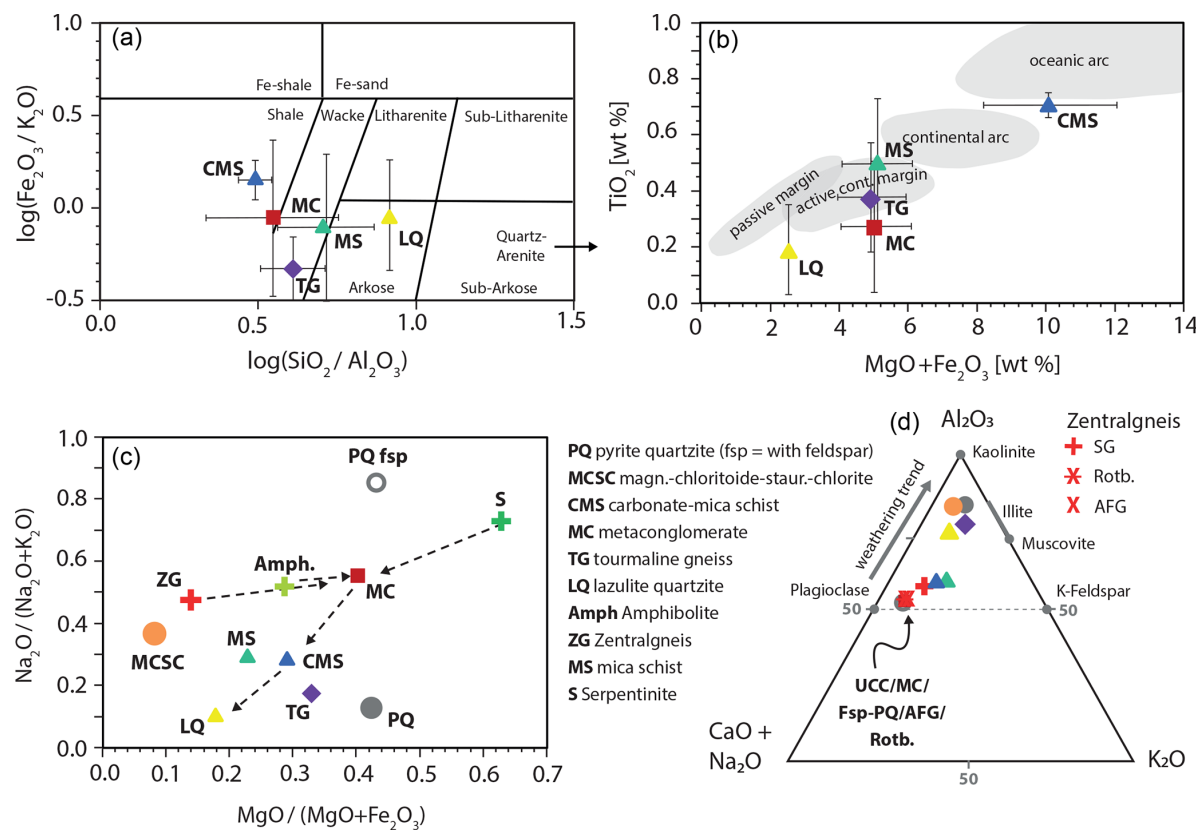

Figure 7. Chemical classification of metasedimentary units and from the Pfitsch-Mörchner basin its basement, using average compositions of the sample set (error bars indicate standard deviation). (a) Classification after Herron (1988); all units plot into the field of coarsegrained protoliths; only the carbonate-mica schist plots into the field of shale. (b) Geotectonic environment (Bhatia, 1983) using the mafic components and $\mathrm{TiO}_{2}$. The data plot close to the field for active continental margins; the low $\mathrm{TiO}_{2}$ contents of lazulite quartzite and metaconglomerate at a given $\mathrm{MgO}+\mathrm{Fe}_{2} \mathrm{O}_{3}$ are explained by dominance of the whole-rock composition by the Zentralgneis source; the high values of $\mathrm{TiO}_{2} / \mathrm{MgO}+\mathrm{Fe}_{2} \mathrm{O}_{3}$ for carbonate-mica schist indicate a higher input of heavy minerals associated with the higher amount of clay (cf. panel a). (c) Average ratios of alkalies $\mathrm{Na}_{2} \mathrm{O} /\left(\mathrm{Na}_{2}+\mathrm{K}_{2} \mathrm{O}\right)\left(\mathrm{Na \#}\right.$; wt \%) and mafic components $\mathrm{MgO} /\left(\mathrm{MgO}+\mathrm{Fe}_{2} \mathrm{O}_{3}\right)(\mathrm{Mg \#}$; wt \%). The metaconglomerate can be explained as a mixture of Zentralgneis (ZG) with amphibolite (using the average composition of the latter as given by Dingeldey, 1992; Steffen and Selverstone, 2006) and serpentinite (dashed arrows). The mica schists and the tourmaline gneiss indicate increasing maturation of the fining-upwards series, and the lazulite quartzite has a well-sorted composition with the lowest Na\# and

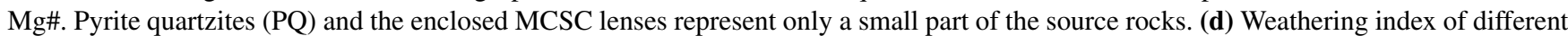
rock series (average molar values, not corrected for $\mathrm{CO}_{3}$; weathering trend according to Nesbitt and Young, 1984). Metaconglomerate, two types of Zentralgneis (Augenflasergneis is AFG, and gneiss from the Rotbachlspitze is Rot), and feldspar-bearing pyrite quartzite plot at the composition of the upper continental crust (UCC) (Rudnick and Gao, 2003). The Schrammacher Gneis variety (SG) lies above the feldspar line, indicating that weathering/alteration of the original granitoid has already taken place. The pyrite quartzite and the MCSC lenses indicate strong alteration.

\subsubsection{Major-element sedimentary classification}

The chemical composition confirms the differentiation of rock units based on field criteria, except for the mica schist and the carbonate-mica schist. Both of these rock types have similar large variations in element contents, and the distinction made in the field by the ankerite-biotite aggregates of the latter type is interpreted as local heterogeneities in an otherwise compositionally similar sediment. Using the common classification diagrams for sediments, we keep in mind the known geologic situation; i.e., the basin was small and restricted in dimensions to not more than tens of kilometers and was likely a continental, not marine, basin (Veselá and Lammerer, 2008). In the classification of Herron (1988), $\mathrm{Fe}_{2} \mathrm{O}_{3} / \mathrm{K}_{2} \mathrm{O}$ ratios are plotted as indicators for mafic to $\mathrm{K}$-feldspar + mica components and $\mathrm{SiO}_{2} / \mathrm{Al}_{2} \mathrm{O}_{3}$ ratios are plotted for quartz to feldspar + mica components. Data for the siliciclastic metasedimentary samples plot in the field of arkose-wacke (Fig. 7a), except for the carbonate-mica schist, which plots outside this region in the field of shale, indicating a higher pelitic content of its protolith. Also, the lazulite quartzite is not a quartz arenite but an arkose or litharenite, consistent with our interpretation of a conglomeratic sandstone (however, we keep the term lazulite quartzite as introduced in the literature for this rock). The metaconglomerate plots at the border between shale and wacke, consistent with the interpretation of Schön and Lammerer (1989) that the percentage of matrix in this rock is high. Using the data in their Table 2, the matrix is calculated to represent an average of $67.5 \mathrm{vol} \%$ of the rock, increasing from 40 to almost 100 vol \% from stratigraphic bottom to top. In such coarsegrained clastic sedimentary rocks, heavy minerals such as zircon, Ti magnetite-ilmenite, and $\mathrm{TiO}_{2}$ polymorphs control the distribution of the HFSEs (Fig. 4g). Based on the rela- 
tionship between $\mathrm{TiO}_{2}$ and the sum of $\mathrm{MgO}+\mathrm{Fe}_{2} \mathrm{O}_{3}$, used to classify the geotectonic environment of sandstones (Bhatia, 1983), these metasedimentary rocks are situated near the field of active continental margins, transitional to the continental arc field (Fig. 7b). The carbonate-mica schist is significantly richer in mafic $\mathrm{MgO}+\mathrm{Fe}_{2} \mathrm{O}_{3}$ and $\mathrm{TiO}_{2}$ contents, comparable to oceanic arc sediments. Keeping in mind the continental character of the basin, this inferred mafic component is interpreted as a locally higher influence of lacustrine (with a higher amount of pelitic material) vs. fluviatile sediments. Data for the metaconglomerate and the lazulite quartzite do not plot in the fields, and this may reflect the coarse-grained nature of their conglomerate protoliths. The plot is designed for sandstones, and hence such values that plot outside the designated fields are consistent with this interpretation.

\subsubsection{Protolith source rock}

All of the analyzed rocks are highly variable in alkali and $\mathrm{Mg}-\mathrm{Fe}$ contents, as illustrated by the lack of correlation between $\mathrm{Na}_{2} \mathrm{O} /\left(\mathrm{Na}_{2} \mathrm{O}+\mathrm{K}_{2} \mathrm{O}\right)=\mathrm{Na} \#$ and $\mathrm{MgO} /\left(\mathrm{MgO}+\mathrm{Fe}_{2} \mathrm{O}_{3}\right)=\mathrm{Mg} \#$ (both in wt \%) (Fig. 7c). However, this diagram is useful in showing that the composition of the metaconglomerate can be represented as a mixture of the Zentralgneis, amphibolite, and serpentinite, in complete accordance with the pebble analysis of Schön and Lammerer (1989) and with the relatively high $\mathrm{Cr}, \mathrm{Ni}$, and $\mathrm{V}$ contents of the metaconglomerate (Fig. 4h). Moving upsection, the metasedimentary rocks show decreasing Na\# and $\mathrm{Mg} \#$ from the metaconglomerate to mica schists and tourmaline gneiss to the lazulite quartzite at the top of the unit. This trend is consistent with increasing compositional maturation of the sediments, within a sedimentation cycle from metaconglomerate to carbonate-mica schist, superimposed on a varying input of the different source rocks in the protolith. The presence of high Cr-V contents (Fig. $4 \mathrm{~h}$ ) and Ni contents throughout the whole series supports this interpretation and argues against the hypothesis that the tourmaline gneiss has a felsic volcanic protolith (Veselá et al., 2011). Whether a rhyolitic volcanoclastic component was present in the sediments cannot be reconstructed, as their chemical composition cannot be distinguished from the granitoid rocks. The lazulite quartzite has the lowest Na\# and Mg\# and, together with the high $\mathrm{SiO}_{2}$ content, is interpreted as a better-sorted, conglomeratic sandstone protolith having a more distal source area compared to the units below. The MCSC lenses and the two varieties of pyrite quartzite do not follow the geochemical trend of the metasedimentary rocks, suggesting they are a part of the source rocks but probably representing only a minor component.

\subsubsection{Chemical weathering and alteration trends}

The metasedimentary series follow a trend parallel to a weathering trend in terms of average relative molar $\mathrm{CaO}+\mathrm{Na}_{2} \mathrm{O}, \mathrm{Al}_{2} \mathrm{O}_{3}$, and $\mathrm{K}_{2} \mathrm{O}$ contents (CIA is chemical index of alteration; Fig. 7d, following Nesbitt and Young, 1984; Fedo et al., 1995). Upper continental crust (UCC; Rudnick and Gao, 2003) and unaltered granitoids generally have an $\mathrm{A}$ value (for the $\mathrm{Al}_{2} \mathrm{O}_{3}$ content) near 50 (e.g., Oeser et al., 2018). The orthogneiss varieties, as one of the likely major source areas for the sedimentary protoliths, have values close to that of UCC, but individual samples can be higher and especially the Schrammacher Gneis plots towards muscoviteillite. As a result, it is possible that these source rocks were already partially weathered. An alternative explanation involves hydrothermal sericitization, because the formation of sericite/kaolinite/pyrophyllite would produce a similar trend.

The values in the CIA plot (Fig. 7d) are not corrected for the presence of carbonate due to the lack of $\mathrm{CO}_{2}$ determinations in our study. Several individual metaconglomerate samples contain carbonate as observed in hand samples (Fig. 3d; see also Schön and Lammerer, 1989). Moreover, some samples from massive layers of the mica schist and tourmaline gneiss also contain carbonate; hence the average $\mathrm{Al}_{2} \mathrm{O}_{3}$ content (Fig. 7d) is a minimum value. Many of the individual samples of high-K tourmaline gneiss show a trend from the orthogneiss towards the A-K side of the triangle, an indication of K metasomatism, interpreted by Fedo et al. (1995) as reflecting the production of authigenic K-feldspar and/or illite in the clastic sediments.

\subsubsection{REE signatures of metasedimentary rocks}

The consistent REE pattern observed in the metasedimentary rocks is similar to the average composition of the PAAS reference material (Fig. 5b) and supports the premise that the Zentralgneis was a major source area (normalization to North American shale composite shows the same, albeit less smooth, patterns). Although only partial data are available for the Zentralgneis (Finger et al., 1993), the REE signature indicates that its precursor is a common granitoid, with Eu values close to 1 following PAAS normalization. The metasedimentary rocks are distinguished from the Zentralgneis by the presence of a negative Eu anomaly in the mica schist and tourmaline gneiss and a positive $\mathrm{Eu}$ anomaly in the lazulite quartzite (Fig. 5b). Morteani and Ackermand (1996) determined partial REE patterns for samples from the lazulite quartzite, which varied depending on sample mineralogy. Our dataset is consistent with their findings, both of which indicate a heterogeneous distribution of the REE-bearing minerals (metamorphosed to Al-P-REE minerals of the goyazite-svanbergite group) within these metasedimentary rocks.

The slightly positive Eu anomaly of the lazulite quartzite at the top of the sedimentary sequence distinguishes it from the 
stratigraphically lower metasedimentary rocks, suggesting that its composition was influenced by other processes such as greater sorting due to deposition from a more distal source area. Its protolith was discussed by Morteani and Ackermand (1996) as most likely a conglomeratic sandstone (based on relict sedimentary structures) from a sabkha-like environment. Deposition in a sabkha-like environment, which explains the partly high $\mathrm{B}, \mathrm{Sr}$, and $\mathrm{Ba}$ contents (Fig. 4e), is similar to our explanation for the protolith as a phosphatic sandstone related to sedimentary facies change, characterized by having Al-P minerals from the florencite-goyazitecrandallite-svanbergite group. Such sediments (generally characterized by Rasmussen, 1996) may locally contain high amounts of $\mathrm{P}$; can be metamorphosed to lazulitebearing quartzites; and have been observed, e.g., from Proterozoic unconformity-related U deposits in Australia (Gaboreau et al., 2005) and many other localities, summarized by Morteani et al. (2006). We adopt this hypothesis as the most likely explanation.

The REE signatures of the pyrite quartzite and associated MCSC lenses, the base of the sedimentary profile in the SE limb (Fig. 2), are also distinct from those of common metasedimentary rocks (PAAS and the majority of the Pfitsch Formation), which is not consistent with the interpretation of the geological map of the Brenner Basistunnel as Triassic quartzites (Brandner et al., 2011). Analysis of the zoning in zircon crystals (Supplement 4.3.7 in Franz et al., 2021) also shows typical hydrothermal alteration zones in otherwise igneous zircon crystals. The MCSC lenses have been interpreted by Barrientos and Selverstone (1987) as a lateritic paleosol, based on high Fe contents and their position near the base of the metasedimentary unit. In this context, the pyrite quartzite could be viewed as having formed in a deep weathering horizon, but both rock types are strongly depleted in light REEs, a pattern that is not typical of a weathering profile. Relative to their unweathered counterparts, weathered rocks tend to be enriched in REEs, with a high ratio of light to heavy REEs due to the absorbance capacity of clay minerals and $\mathrm{Fe}$ oxides/hydroxides for light REEs (e.g., Aubert et al., 2001; Foley and Ayuso, 2015; Padrones et al., 2017). Soils enriched in heavy REEs relative to light REEs also occur (e.g., Bao and Zhao, 2008), but they are the exception even within weathering profiles and are unlikely to explain the distinct REE signatures of the MCSC lenses and pyrite quartzite (Fig. 5). We interpret the unusual REE patterns of the pyrite quartzite with the MCSC lenses (Fig. 5) as reflecting protoliths of felsic igneous rocks that were hydrothermally altered, because similar (chondrite-normalized) REE patterns were observed in hydrothermally altered igneous rocks. For example, a large dataset of hydrothermally altered dacitic rocks from a volcanic arc in Turkey compiled by Karakaya et al. (2010) shows that alteration can produce REE patterns very similar to those observed herein. Lottermoser (1992) pointed out that such a strong depletion requires a high fluid / rock ratio during alteration. Kyan- ite quartzites in the USA from Virginia and the Carolinas (Owens and Paseck, 2007; Owens and Hollingsworth, 2018) were interpreted as metamorphosed hydrothermally altered igneous rocks, which have similar REE patterns to those studied here, albeit less strongly depleted in the light REEs. The extremely low ratio of light to heavy REEs observed in our samples might have been reinforced during dewatering reactions of the alteration minerals during metamorphism, when light REEs are more mobile than heavy REEs (e.g., Brunsmann et al., 2001).

Because the whole metasedimentary sequence is part of the Greiner shear zone (depicted in Behrmann, 1988, and Behrmann and Frisch, 1990, as a 1-2 km wide strongly sheared zone), an alternative protolith for the pyrite quartzite would be the Zentralgneis, locally hydrothermally altered during shearing, similar to the Zentralgneis further east (at Stilluptal; Selverstone et al., 1991). In the Pfitscher Joch area, Barnes et al. (2004) characterize the shear zone rocks along the northwestern limb within the Zentralgneis as localized zones, up to $10 \mathrm{~m}$ wide, with a pronounced shear foliation and characterized by an increase in phengite and biotite, with millimeter-sized garnets. In the area between Stilluptal and Pfitscher Joch, they describe numerous other shear zones, based on the abundance of chloritites, biotitites, and biotite-chlorite schists, superficially resembling common pelitic rocks.

\subsection{Behavior of $\mathbf{R b}-\mathrm{K}$}

\subsubsection{Hydrothermal alteration of pyrite quartzite and MCSC lenses protoliths}

The behavior of $\mathrm{Rb}$ and $\mathrm{K}$ yields additional information on protoliths and the processes that led to present compositions (Fig. 8). From a crystal chemical point of view, $\mathrm{Rb}$ is strongly coupled to K. In equilibrium with hydrous fluids,

$\mathrm{Rb}^{\text {hydrous fluid }}+\mathrm{K}^{\text {mineral }}=\mathrm{K}^{\text {hydrous fluid }}+\mathrm{Rb}^{\text {mineral }}$.

$\mathrm{Rb}$ fractionates preferentially into mica and feldspar (experimental data at 600 to $800^{\circ} \mathrm{C}$; Melzer and Wunder, 2000, 2001; Tauson et al., 2001) due to the ideal ionic radius of $\mathrm{Rb}$ for substitution in mica and feldspar structures. Measured data in formation waters from the Appalachian Basin (Osborne et al., 2012) show that this trend is also valid at low temperatures; all hydrous fluids (formation waters) are significantly enriched in $\mathrm{K}$ relative to $\mathrm{Rb}$. A low value of $\mathrm{Rb} / \mathrm{K}=0.004$ is therefore typical of UCC and corresponds to $\mathrm{K} / \mathrm{Rb}=250$ (expressed in mass \%). An increase in $\mathrm{Rb} / \mathrm{K}$ in a rock can occur with strong fluid-rock interactions, such as shearing with the production of mica, or during weathering with the production of illite. A smaller $\mathrm{Rb} / \mathrm{K}$, shifting equilibrium (1) to the left, can occur if the activity of water in the hydrous fluid is significantly reduced, e.g., by other fluid components such as $\mathrm{Cl}^{-}$or $\mathrm{SO}_{4}^{2-}$ during pro- 


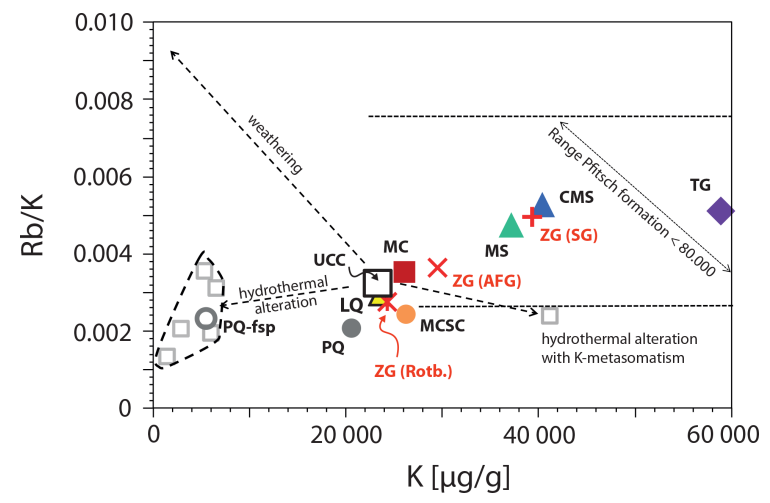

Figure 8. $\mathrm{Rb} / \mathrm{K}$ vs. $\mathrm{K}$ as indicator of metamorphic and premetamorphic processes on protoliths. Plotted are average values from metasediments and basement of the Pfitsch-Mörchner basin. The large scatter of $\mathrm{Rb} / \mathrm{K}$ and the variable and high $\mathrm{K}$ contents of the Pfitsch Formation (tourmaline gneiss, mica schist, carbonatemica schist) are explained by being partly inherited from the source rock, dominated by Zentralgneis types, overprinted by variable intensity of diagenetic illite and/or K-feldspar formation (see text). The low values of $\mathrm{Rb} / \mathrm{K}$ for the pyrite quartzite, especially the feldspar-bearing variety, and its MCSC lenses are consistent with the interpretation that their protoliths were hydrothermally altered rocks. Abbreviations for Zentralgneis: ZG Rot is Zillertal unit, from Rotbachlspitze; ZG AFG is Tux unit, Augenflasergneis; ZG SG is Schrammacher Gneis, Tux unit; dashed arrows indicate the influence of hydrothermal alteration and weathering on protoliths (Oeser et al., 2017; UCC is upper continental crust from Rudnick and Gao, 2003). Examples for hydrothermal alteration of granitoids and granitoid-derived deposits are (grey open squares, listed from high to low Rb / K) Asarel, Bulgaria (Hikov, 2013); Horn Mine, Virginia, USA (Owens and Paseck, 2007); Loma Blanca, Argentina (Marfil et al., 2010); Oyu Tolgoi, Mongolia (Kashgerel et al., 2001); and Sanshandao, China (Li et al., 2013), which is given as an example of enrichment of $\mathrm{K}$ during hydrothermal alteration of granitoids.

cesses such as diagenesis with basin brines or hydrothermal alteration.

The variable $\mathrm{Rb} / \mathrm{K}$ ratios and $\mathrm{K}$ contents in the rock units from the Pfitsch area are distinctive (Fig. 8). Weathering with loss of $\mathrm{K}$ is expected to increase $\mathrm{Rb} / \mathrm{K}$ up to values near 0.010 (Oeser et al., 2017). Shearing also produces an increase in $\mathrm{Rb} / \mathrm{K}$ from $\sim 0.003$ to 0.005 , accompanied by an increase in $\mathrm{K}$ from $2.7 \mathrm{wt} \%$ to $6.3 \mathrm{wt} \% \mathrm{~K}_{2} \mathrm{O}$ (data from Selverstone et al., 1991, for the Greiner shear zone). We have shown above that the trend of the weathering index of the pyrite quartzite (Fig. 7d) can alternatively be explained by sericitization or pyrophyllite formation, typical of hydrothermal alteration of felsic igneous rocks, and examination of $\mathrm{Rb} / \mathrm{K}$ values serves as an additional indication of hydrothermal alteration, decoupling it from a weathering profile or a shear zone. There are many examples in the literature that illustrate the effect of hydrothermal alteration on granitoids and their associated mineral deposits: e.g., Oyu Tolgoi (Mongolia; Kashgerel et al., 2001), Loma
Blanca (Argentina; Marfil et al., 2010), Horne mine (Quebec, Canada; MacLean and Hoy, 1991), and Azarel (Bulgaria; Hikov, 2013). All show Rb / K ratios that are typically lower than or equal to those of UCC. Note, however, that the nature of hydrothermal alteration (e.g., silicification, advanced argillic alteration, alunite or pyrite sericitization, propylitization, and $\mathrm{K}$ metasomatism) and associated products can be quite variable. The host rock to the Sanshandao gold deposit in China ( $\mathrm{Li}$ et al., 2013) serves as an example of a granitoid that experienced $\mathrm{K}$ enrichment during alteration but also with decreasing $\mathrm{Rb} / \mathrm{K}$ (Fig. 8). Examples from the literature show that the presence of kyanite quartzites with pyrite can be explained as the metamorphic equivalent of rocks that experienced argillic alteration (Virginia Plutonic Belt, USA; Owens and Paseck, 2007; Owens and Hollingsworth, 2018). The conceptual model that hydrothermally altered granitoids are the protoliths for the pyrite quartzite is also in line with the pervasive $\mathrm{S}$ enrichment (up to almost $1 \mathrm{wt} \% \mathrm{SO}_{3}$ ) either directly with formation of pyrite or as sulfates such as alunite $\mathrm{KAl}_{3}\left(\mathrm{SO}_{4}\right)_{2}(\mathrm{OH})_{6}$, which were reduced during metamorphism to pyrite.

In the case of the Pfitsch-Mörchner basement, the Rb / K ratios of the pyrite quartzite and MCSC lenses are lower than that of UCC, suggesting that the protolith experienced hydrothermal alteration prior to metamorphism. The excellent correlation of the $\mathrm{Rb} / \mathrm{K}$ ratios with $\mathrm{K}$ (Fig. 4d) for these rocks indicates well-equilibrated rocks, consistent with alteration at high fluid / rock ratios. Our interpretation is in line with the report of argillic alteration of the Zentralgneis during formation of the molybdenite deposit at the Alpeinerscharte (see Fig. 1; Mostler et al., 1982; Melcher et al., 1996). The mineral assemblage of the MCSC lenses (staurolitemagnetite-chloritoid within the quartzite) could then represent mafic (amphibolitic) enclaves in such rocks, as described in the Zillertal Zentralgneis further east in the Greiner shear zone (Selverstone et al., 1991). The unusual REE patterns with extremely low light REEs of the pyrite quartzite and the MCSC lenses (Fig. 5) are also consistent with our interpretation that the protoliths of these rocks were hydrothermally altered, felsic, igneous rocks. Because the entire series underlies the metaconglomerate, these rocks must have been near to the erosional surface before deposition of the Pfitsch metasedimentary rocks and therefore likely experienced the additional influence of weathering superimposed on the hydrothermal signature.

\subsubsection{Diagenetic signature in the tourmaline gneiss and mica schists}

The tourmaline gneiss and, to a lesser extent, the mica schists stand out with high $\mathrm{K}$ contents, up to $\sim 10 \mathrm{wt} \% \mathrm{~K}_{2} \mathrm{O}$ $(\sim 8 \mathrm{wt} \% \mathrm{~K})$, and quite variable $\mathrm{Rb} / \mathrm{K}$ ratios of 0.002 to 0.008 (Figs. 4d, 8). This composition partly reflects the inferred source rocks, which also have $\mathrm{Rb} / \mathrm{K}$ ratios that vary between $\sim 0.003$ and $\sim 0.008$. Weathering is less likely to 
be an important process, as it would generally lead to $\mathrm{K}$ depletion, rather than enrichment. Instead, it has been shown that during diagenesis of mudstone-sandstone strata at temperatures of $\sim 20$ to $\sim 200^{\circ} \mathrm{C}, \mathrm{K}_{2} \mathrm{O}$ contents can increase from averages of $\sim 4 \mathrm{wt} \%$ to $\sim 7 \mathrm{wt} \%$ up to a maximum of 9 wt \% (e.g., Day-Sirrat et al., 2010). Thyne (2001) developed a model for diagenetic mass transfer between sandstone and shale and clearly showed that within a single rock unit, depending on porosity and the initial distribution of illite and authigenic K-feldspar, significant transport of $\mathrm{K}$ over a scale of several meters is possible. In order to explain the high $\mathrm{K}$ contents in the tourmaline gneiss, we refer to a model developed by Leising et al. (1995) for Tertiary basins in New Mexico and Arizona. In these lacustrine, intramontane environments, evaporation-induced dense brines can form descending, density-driven plumes, provided that the porosity of the rocks allows vertical convection. This process has been identified as a cause of strong $\mathrm{K}$ metasomatism leading to the formation of arkosic rocks with $8 \mathrm{wt} \%-12 \mathrm{wt} \% \mathrm{~K}_{2} \mathrm{O}$ (Leising et al., 1995) and is in line with the elevated $\mathrm{K}$ contents observed throughout the Pfitsch Formation.

Diagenesis can also fractionate $\mathrm{Rb}$ from $\mathrm{K}$, leading to depletion of $\mathrm{Rb}$ relative to $\mathrm{K}$ and low $\mathrm{Rb} / \mathrm{K}$ ratios. For example, Brueckner and Snyder (1985) reported decreasing $\mathrm{Rb} / \mathrm{K}$ ratios from 0.006 to 0.0015 in siliceous sediments as a result of diagenesis. A similar trend was observed by Land et al. (1997) for a sandstone having a composition close to that of UCC down to an $\mathrm{Rb} / \mathrm{K}$ of $\sim 0.002$. The variation in the $\mathrm{Rb} / \mathrm{K}$ ratio of the tourmaline gneiss in the Pfitscher Joch area $(0.004-0.008)$ is therefore interpreted to reflect (i) variation in the source rocks and (ii) variable enrichment in diagenetic illite/K-feldspar (Day-Stirrat et al., 2010). As a result, diagenesis can produce changes to the whole-rock composition that are much more significant than those that occurred during Alpine greenschist to amphibolite facies metamorphism, because porosity in a sediment allows for pervasive fluid transport, whereas in metamorphic rocks pervasive fluid transport is limited except where focused or channeled in shear zones or faults (e.g., Skelton et al., 1995).

\subsection{The B and B-isotope record}

\subsubsection{Boron in the basement units}

The final B-isotope composition of the metasedimentary rocks reflects three major stages: (1) detrital B inherited from the source rocks; (2) interaction of unlithified sediments with (sub)surface fluids during transport, sedimentation, and early to late diagenesis; and (3) mobilization and fractionation during metamorphism. Before conclusions can be drawn from the B-isotope signature of the metasedimentary rocks, the inventory of the B and B-isotope record must be unraveled for each of these stages. We have shown that protoliths of the Zentralgneis and its country rocks served as the main sources for the metasedimentary protoliths. The B and B- isotope signatures of the different basement rocks are relatively distinct (Fig. 6), having an average B concentration of $6 \mu \mathrm{g} \mathrm{g}^{-1}$ and average $\delta^{11} \mathrm{~B}$ value of $-10 \%$. The Zentralgneis has $\delta^{11} \mathrm{~B}$ values from $-1.5 \%$ o to $-3.5 \%$, which is within the range commonly observed for S- and A-type granitoids (Trumbull et al., 2020); the blackwall zones around serpentinite bodies have B-isotope values of -16 to $-9.5 \%$; a similar range is reported for blackwall zones at the Habachtal serpentinite further east of the Pfitscher Joch area $(-14 \%$ o to $-5 \%$; Trumbull et al., 2008). Only the Furtschagl schist, the lowermost unit below the Zentralgneis in the SE, has a notably light isotope signature of $-17.1 \%$ (Fig. 6), but there is no indication that these rocks represent an important part of the sedimentary source (Schön and Lammerer, 1989; discussion above). The B-isotope value of the pyrite quartzite is slightly more negative than the Zentralgneis unit (Fig. 6), which is consistent with the interpretation of its protolith as a hydrothermally altered granitoid, with small isotope fractionation occurring during alteration and Alpine metamorphism.

The average whole-rock B contents of the basement $\left(6 \mu \mathrm{g} \mathrm{g}^{-1}\right)$ are low compared to those of the tourmaline gneiss and mica schists $\left(215 \mu \mathrm{g} \mathrm{g}^{-1}\right.$ of B) and even lower than the average B content of UCC (17 $\mu \mathrm{gg}^{-1}$; Rudnick and Gao, 2003). Although tourmaline has been observed in segregations (such as sample PJ101 and a tourmaline-bearing segregation in the pyrite quartzite, sample PJ49a+53) and in the blackwall rocks near serpentinites, it is generally rare. Due to a minor detrital tourmaline component, we conclude that detrital B input is governed by B hosted in muscovite-illite in the original sediments, and hence the contribution of a clastic sedimentary source to the overall B budget of the Pfitsch Formation is negligible.

\subsection{2 $B$ in the metasedimentary units}

Most of the metasedimentary rocks display $\delta^{11} \mathrm{~B}$ signatures distinctly lower than those of the basement rocks (Fig. 6) and have high average $\mathrm{B}$ contents of $215 \mu \mathrm{g} \mathrm{g}^{-1}$, hosted by tourmaline. In our previous study (Berryman et al., 2017), we showed that tourmaline in the tourmaline gneiss and mica schist is metamorphic in origin, forming on both the prograde and the retrograde paths. As prograde metamorphism of sedimentary rocks is typically associated with net removal of B by fluids expelled through dehydration reactions (Bebout and Graham, 2007; Bebout and Nakamura, 2003), the addition of $\mathrm{B}$ in the metasedimentary rocks of the Pfitscher Joch area must have occurred prior to Alpine metamorphism. A likely process of $\mathrm{B}$ acquisition is by adsorption onto clay minerals and by subsequent incorporation into illite in tetrahedral coordination (Williams et al., 2001) from subsurface waters circulating in the sediments during diagenesis, such that the B content of the sediments correlates with the clay fraction. This explanation is consistent with local variation in B contents within the tourmaline gneiss. For instance, a sample with a gneissic fabric (sample no. 28-17) has a low 
$\mathrm{Rb} / \mathrm{K}$ ratio (0.0038), contrasted by a sample with a schistose fabric (no. 28-11) and higher $\mathrm{Rb} / \mathrm{K}$ (0.0067). As per Sect. 3.2 above, the protolith of the latter sample shows a stronger diagenetic signature and hence likely had a greater amount of clay, which additionally explains its higher B content $\left(516 \mu \mathrm{gg}^{-1}\right.$ at $\left.-14.4 \% \circ \delta^{11} \mathrm{~B}\right)$ relative to the gneissic sample $\left(165 \mu \mathrm{g} \mathrm{g}^{-1}\right.$ at $\left.-16 \% \circ \delta^{11} \mathrm{~B}\right)$. Local variations in the abundance of tourmaline can be attributed to variations in the $\mathrm{B}$ content of the protoliths, which in turn is affected by prevalence of illite with a relatively fixed B content (adsorbed B is likely lost to the fluid during early diagenesis; Williams et al., 2001). The metaconglomerate is the coarse-grained basis of a fining-upwards sedimentary sequence and indeed shows the lowest whole-rock B contents $\left(7.1 \mu \mathrm{g} \mathrm{g}^{-1}\right.$ of B at $-15.8 \% \circ \delta^{11} \mathrm{~B}$ ), which is only slightly higher than the average whole-rock B content of the basement rocks ( $5 \mu \mathrm{g} \mathrm{g}^{-1}$ of B).

\subsubsection{B source}

The B-isotope signatures of the metasedimentary rocks can provide insight into the source of the B that was deposited during diagenesis of the protoliths. Trumbull et al. (2020) showed that marine evaporites have B-isotope signatures of ca. $+12 \%$ o to $40 \%$ whereas those of non-marine evaporites are $-30 \%$ o to $+25 \%$. The $-33 \%$ o to $-14 \%$ o $\delta^{11} \mathrm{~B}$ signature of the metasedimentary rocks in the study area is therefore most consistent with deposition in a continental, lacustrine basin. Clastic sediments have a similar range $(-25 \%$ o to $+10 \%$ o) to non-marine evaporites, but since major detrital $\mathrm{B}$ input is unlikely (see above), the high B contents point to high levels of evaporation. Evaporites have been reported to occur up-section in the lazulite quartzite of the Windtal Formation (Morteani and Ackermand, 1996) and in marble of the Aigerbach Formation (Vesalá and Lammerer, 2008), in agreement with the low latitudes of 0 to $20^{\circ} \mathrm{N}$ of the area during the Permo-Triassic (Scotese and Schettino, 2013). Our proposal of evaporation-induced, dense brines that formed descending, density-driven plumes (Leising et al., 1995), suggested as a cause of strong $\mathrm{K}$ metasomatism leading to the formation of arkosic rocks with $8 \mathrm{wt} \%-12 \mathrm{wt} \% \mathrm{~K}_{2} \mathrm{O}$, is also considered responsible for the observed high $\mathrm{B}$ content and the very low B-isotope signature.

Boron minerals from evaporitic deposits show a wide range of B-isotope ratios; e.g., Kasemann et al. (2016) reported values from $-30 \%$ to $0 \% \circ \delta^{11} \mathrm{~B}$ for borates of the Andean salt lakes in Argentina and in part heavier values $(-18 \%$ to $0 \%$ o $)$ in the geothermal fluids. Assuming such fluids represent a source of the locally high B contents in the Pfitsch-Mörchner basin and their diagenetic interaction in descending brines with clay minerals, fractionation of $\mathrm{B}$ isotopes between fluid and clay minerals on the order of $-15 \%$ to $-30 \% \circ \Delta^{11} \mathrm{~B}$ (increasing with decreasing temperature; Williams et al., 2001) can explain both the partly extreme values of $-33 \% \delta^{11} \mathrm{~B}$ and the large isotopic variation.
The ultimate source of B is probably related to igneous volcanic arc rocks and their geothermal fluids.

\subsubsection{Tourmalinite veins in the lazulite quartzite}

The origin of the hydrothermal tourmalinite veins is enigmatic. Many tourmalinites are genetically related to hydrothermal events associated with felsic igneous rocks and ore deposits (Slack and Trumbull, 2011; Trumbull et al., 2020); hence their formation could be assigned to hydrothermal activity during intrusion of the Zentralgneis protolith and associated volcanic activity. However, the relative ages exclude a genetic relation to the Zentralgneis, which is much older (Carboniferous to Permian) than the metasedimentary rocks. Tourmalinite veins appear throughout the metasedimentary unit ranging from the metaconglomerate to the Lower Triassic lazulite quartzite (Fig. 3g, h). These veins cut the original bedding (Fig. 3i; Supplement 4.3.6 in Franz et al., 2021, and figures in Henry et al., 2002), which requires that the precursor sediments were already consolidated and lithified at the time of tourmalinite emplacement and which distinguishes them from stratabound tourmalinites in metaevaporite sequences as described by Henry et al. (2008), formed during early diagenesis.

Tourmaline in the tourmalinite veins is commonly very fine grained (typically $\leq 50 \mu \mathrm{m}$; Fig. 3i), with the exception of crystals up to $800 \times 2500 \mu \mathrm{m}$ in size that occur in strongly Alpine-deformed tourmalinite clasts (Henry et al., 2002). This distinguishes the tourmalinites from (1) prograde metamorphic tourmaline in the metasediments and (2) tourmaline crystals from Alpine fissures and segregations, found elsewhere in the Pfitscher Joch that formed post-peak on the retrograde path. Since these are millimeters to centimeters in length (Berryman et al., 2017), the very fine grained nature of the tourmalinites is incompatible with a formation during Alpine peak retrograde metamorphism.

Instead, the small crystal size of the tourmalinites points to the tourmalinites being remnants of a quenched B-rich fluid, and their bimodal character with tourmaline-rich and quartzrich layers indicates that they exsolved from a homogenous B-rich fluid into a B-rich and a silicate-rich phase. Experimental investigations of $\mathrm{B}$ solubility in the system $\mathrm{Na}_{2} \mathrm{O}-$ $\mathrm{B}_{2} \mathrm{O}_{3}-\mathrm{SiO}_{2}-\mathrm{H}_{2} \mathrm{O}$ have proved the existence of immiscible and colloidal $\mathrm{Na}-\mathrm{B}$ silicate liquids at $520^{\circ} \mathrm{C} / 1.5 \mathrm{kbar}$ and $\mathrm{Na}_{2} \mathrm{O}$ contents of $>3 \mathrm{wt} \%$ (Smirnov et al., 2005). The fact that tourmalinite formation in the Pfitscher Joch must have occurred at much lower temperatures somewhere above zeolite-facies conditions (Henry et al., 2002) and below the peak metamorphic temperature of $\sim 550^{\circ} \mathrm{C}$ is not a counterargument here, because fluid immiscibility has also been observed at temperatures between 200 and $400^{\circ} \mathrm{C}$ (Kravchuk and Valyashko, 1979; Valyashko, 1990). The latter experiments were performed in the B-free system $\mathrm{Na}_{2} \mathrm{O}$ $\mathrm{SiO}_{2}-\mathrm{H}_{2} \mathrm{O}$, but following the interpretations of Smirnov et al. (2005), the occurrence of a fluid solvus is not related to B 
but rather restricted to systems having elevated Na concentrations. Assuming a temperature of $300^{\circ} \mathrm{C}$ and given the $\mathrm{Na}$ content in the earliest generation of tourmaline in the tourmalinite ( $0.7 \mathrm{Na}$ pfu; Henry et al., 2002), the extrapolated partitioning coefficients derived by von Goerne et al. (2001) indicate an $\mathrm{Na}$ concentration of $0.5 \mathrm{~mol} \mathrm{~L}^{-1}\left(3.1 \mathrm{wt} \% \mathrm{Na}_{2} \mathrm{O}\right)$ in the fluid. This is just above the threshold of the $\mathrm{Na}$ content postulated by Smirnov et al. (2005) required for forming a colloidal Na-B silicate liquid.

Concerning the B source for the tourmalinites, the dense brines, which in our model caused the $\mathrm{K}$ metasomatism and $\mathrm{B}$ enrichment in the tourmaline gneiss and mica schist unit, are the most likely candidates. We hypothesize that B from these pre-enriched sedimentary units was mobilized in pore waters and concentrated by hydrothermal fluids, from which an Na-B-rich silicate liquid exsolved and formed the tourmalinites by reaction with Al-rich country rocks. In contrast, mobilization of $\mathrm{B}$ from the lazulite quartzite into a vein is unlikely. This is concluded from the decrease in B concentration from $193 \mu \mathrm{g} \mathrm{g}^{-1}\left(\delta^{11} \mathrm{~B}-10.4 \%\right.$ o $)$ in the lazulite quartzite close to a tourmalinite vein to $29 \mu \mathrm{g} \mathrm{g}^{-1}$ of $\mathrm{B}\left(\delta^{11} \mathrm{~B}\right.$ $-11.9 \%$ ) in the more distal lazulite quartzites, which rather points to the opposite movement of B from the vein into the lazulite quartzite. The tourmalinite precursor fluid was also enriched in isotopically heavy $\mathrm{B}$, because tourmalinite veins in the study area have a $\delta^{11} \mathrm{~B}$ value of $-9.88 \%$, which is lower than those of any of the metasedimentary whole-rock values in the Pfitsch area. Given the decrease in $\delta^{11} \mathrm{~B}$ of the lazulite quartzite with increasing distance to the tourmalinite vein, the lazulite quartzite likely had a $\delta^{11} \mathrm{~B}$ signature of $\ll 11.9 \%$ o, probably close to those of the tourmaline gneiss and mica schists.

If deposition of the tourmalinites during peak and postpeak Alpine metamorphism can be excluded, their formation must have occurred during a hydrothermal event unrelated to this metamorphism. There is growing evidence in the Alps for Permian and later hydrothermal events and/or metamorphism (review in Schuster and Stüwe, 2018) and magmatism (e.g., Yuan et al., 2020). In the Collio basin of the Orobic Alps (to the southwest of the Tauern Window), this magmatism is also associated with tourmalinization (De Capitani et al., 1999) and tourmalinites (Slack et al., 1996). In the Pfitscher Joch area, the (now-metamorphosed) mafic dike swarm within the Zentralgneis (Fig. 3b) might be a remnant of such an event. The intrusion of these basalts has not been dated, but comparison with mafic magmatism in similar basins south and north of the Tauern Window hints at a Triassic age (see discussion below).

\subsection{Implications for paleogeography and regional geology}

The chemical signatures of the metasedimentary rocks of the Pfitsch-Mörchner basin allow us to reconstruct the following pre-metamorphic history. At the time of sediment ero- sion and transport, the crystalline basement, consisting of granitoids and related roof pendants with amphibolites, serpentinites, and gneisses, was exposed to an arid to semiarid climate, likely characterized by strong physical weathering (Fig. 9). This is in line with the low latitudes for the position of this part of Eurasian continental crust at the Permian-Triassic (Scotese and Schettino, 2017). Portions of the granitoids might have experienced strong hydrothermal alteration and weathering, with such rocks then being transformed during Alpine metamorphism into the characteristic pyrite quartzite. According to chemical classifications of the metasedimentary rocks, the hinterland was a continental volcanic arc, in line with subduction-related magmatism producing the Zentralgneis granitoids (e.g., Finger et al., 1993; Cesare et al., 2001) and the associated, porphyry-related molybdenite deposit (Melcher et al., 1996). The presence of coarse conglomerates and breccias on the base of this major erosional nonconformity supports a proximal position of the sediment source area. A closed intramontane Permian basin (Veselá and Lammerer, 2008, and references therein) is completely in accordance with the data as are the high B contents and very low $\delta^{11} \mathrm{~B}$ values, typical of lacustrine, saline basins. Sedimentation was dominated by fluvial-lacustrine sediments, with indications of organic-rich sediments being absent. The interpretation here of the tourmaline-bearing gneiss as a meta-arkose, in contrast to a meta-rhyolite protolith by Veselá and Lammerer (2008), is important. Within our metasedimentary interpretation, the zircons from this unit dated by Veselá et al. (2011) are proposed as detrital. The presence of zircon indicates volcanism in the source area, defining a maximum age of sedimentation as $280 \pm 3 \mathrm{Ma}$.

On top of the Pfitsch Formation, a sedimentary facies change is represented by the Windtal lazulite quartzite with distal transport producing the well-sorted sediment, possibly already existing near the seashore, as hypothesized by Morteani and Ackermand (1996) in a saline lagoon, or sabkha, environment (Fig. 9). Further east, in the Slovenian Karawanken mountains, marine shallow-water carbonates at the Permian-Triassic boundary are exposed in the Brsnina section (Williams et al., 2021) and are also explained as deposited at hypersaline conditions in a sabkha. It remains open if the transition from the Pfitsch Formation to the Windtal Formation is a sequence boundary or a disconformity (with a period of no deposition), but phosphatic sandstones, metamorphosed into Al-P quartzite (Morteani et al., 2007), are often associated with unconformities. From a similar continental setting in the Cañizar and Eslida formations of the south Iberian range (Spain), Galán-Abellán et al. (2013) described Early Triassic Al-P sandstones and the development of Al-P minerals during early diagenetic interaction with acidic meteoric waters. There are numerous other reports of Al-P sandstones related to unconformities, e.g., Gaboreau et al. $(2005,2007)$ from Proterozoic basins in Canada and Australia and Pe-Piper and Dolansky (2005) from the terrestrial Cretaceous Chaswood Formation in Nova Scotia, Canada. 


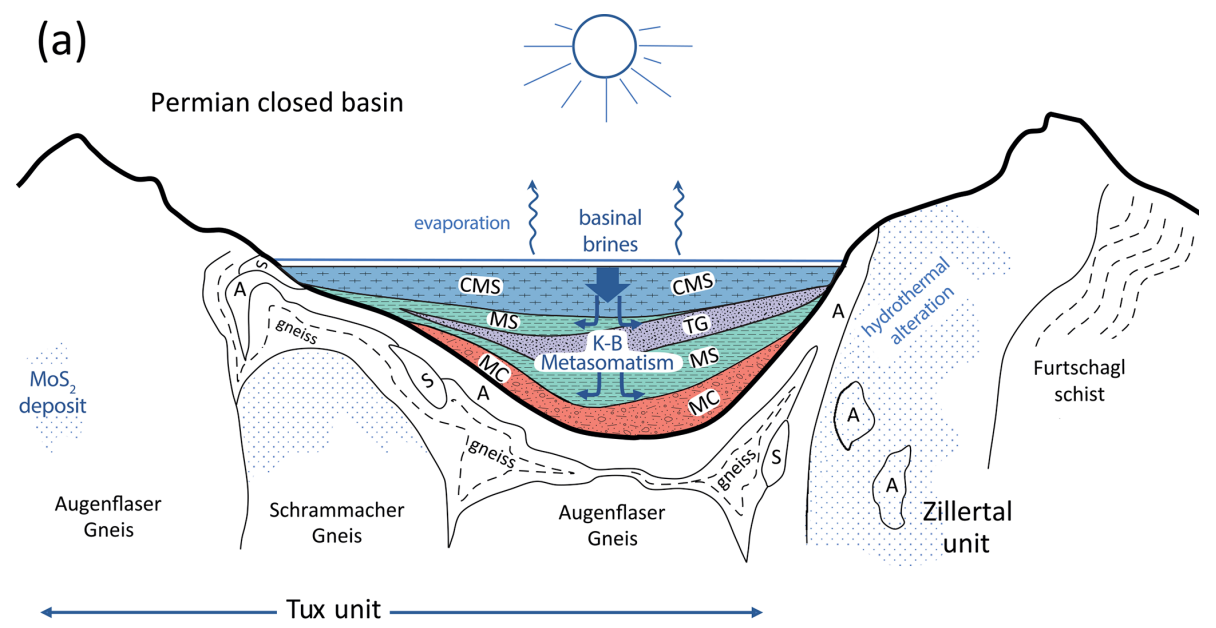

(b)

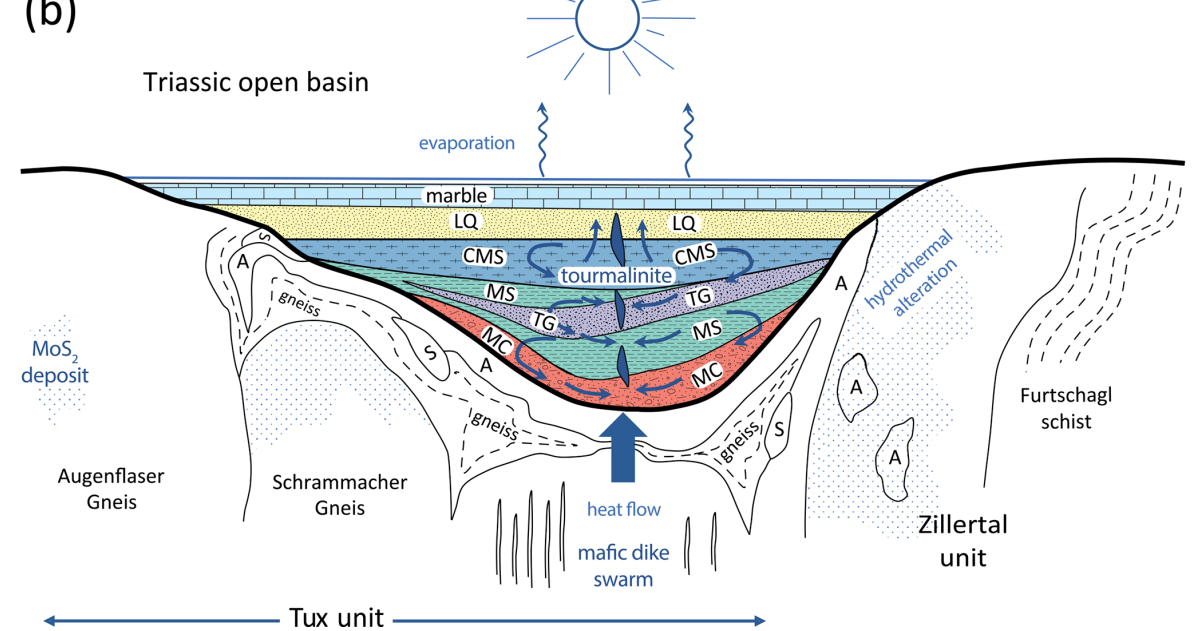

Figure 9. Schematic cross sections of the Pfitsch-Mörchner basin at the Permian (a) and Triassic (b) (not to scale). Sedimentation of the Pfitsch Formation started with coarse conglomerates (preserved as metaconglomerate, MC) from proximal source rocks, the Variscan mountain chain with dominantly granites, partly with hydrothermal alteration (e.g., the molybdenite deposit at the Alpeinerscharte; cf. Fig. 1) in the Tux unit. The roof pendant of the granites consists of gneiss, amphibolite (A), and serpentinite (S). During the Permian, the sedimentary protoliths (especially for tourmaline gneiss, TG, and mica schist, MS, and carbonate-mica schist, CMS) of the closed, intramontane basin with evaporitic deposits were influenced by diagenetic descending, highly saline brines, which caused K and B metasomatism. The Triassic marks the transition from a closed to an open basin with deposition of well-sorted (distal transport) conglomeratic phosphatic sandstone (protolith of the lazulite quartzite, LQ, Windtal Formation), possibly connected with a disconformity, overlain by shallow-water carbonates (Aigerbach Formation marble horizon). Formation of tourmalinite veins is due to hydrothermal circulation of B-rich pore waters in the basin. Increased heat flow in the basin is produced by intrusion of mafic dikes into the Tux branch of the granites.

Hall et al. (1997) identified Al-P minerals on a former karstic erosional surface, derived from the leaching and dissolution of pre-depositional carbonates (Pennsylvanian Cheltenham Formation, Missouri, USA), and Mordberg et al. (2000) described Al-P minerals in a Devonian bauxitic weathering profile on Precambrian alkaline rocks in the Timan Range, northern European Russia. In the Pfitsch-Mörchner basin, lazulite quartzite marks the transition from a closed intramontane basin to an open basin, possibly connected with a disconformity. The depositional age of this and the next unit above, the Aigerbach Formation marble, is not restricted by radiometric age data, but comparison with the sedimentary record on the northern, Eurasian part of the basement allows for the hypothesis in which they are Early and Middle Triassic (Lammerer, 1986), corresponding to the classic "Germanic trilogy Buntsandstein-Muschelkalk-Keuper". Radiogenic ${ }^{87} \mathrm{Sr} /{ }^{86} \mathrm{Sr}$ for the marble and the Pfitsch Formation (Supplement 4.3.3 in Franz et al., 2021), which were deter- 
mined to check for a stratigraphic correlation, are in line with this hypothesis but due to the likely influence of $\mathrm{Rb}$ in the marble do not allow a more detailed interpretation.

South of the Pfitscher Joch area in the South Alpine realm, other unmetamorphosed or only slightly metamorphosed Permo-Mesozoic sedimentary basins are known, such as the Collio and Tione basins. In the Tione basin near the city of Trento, a sedimentary sequence of similar age was described by Cortesogno et al. (1998). Its basement also consists of late Hercynian granitoids ("Dos del Sabion") with diverse metamorphic country rocks (cf. Zentralgneis with Altes Dach). The cover sequence begins with coarse fluvial-lacustrine deposits of the Permian Collio Formation (cf. metaconglomerates of the Pfitsch Formation), separated by an unconformity from the overlying medium- to coarse-grained Val Daone conglomerates (cf. mica schist unit and tourmaline gneiss). This sequence leads into the detrital Verrucano Lombardo-Val Gardena deposits, which are covered by Lower Triassic sandstones and limestone of the Servino Formation (cf. lazulite quartzite and Aigerbach Formation marble). However, there are also significant differences among these sequences, because the Tione basin contains a large amount of dacitic to andesitic volcanic rocks, which are absent in the Pfitscher Joch area.

The Permo-Triassic was a time of major extensional stress, which affected Eurasia in the western European domain (Nikishin et al., 2002), producing several terrestrial basins in the Southern Alps. Cassinis et al. (2008) documented mafic magmatism throughout these basins and their crystalline basements, occurring as mafic dike swarms/sills having a Late Triassic age of $217 \pm 3 \mathrm{Ma}$ (Ar-Ar dating) in the Tione basin. In the Collio basin to the west, Feijth (2002) determined the $\mathrm{Ar}-\mathrm{Ar}$ age of detrital white mica and interpreted ages of 270 to $255 \mathrm{Ma}$ and 250 to $180 \mathrm{Ma}$ as records of hydrothermal events. In line with these observations, the metamorphosed dikes in the Zentralgneis of the Pfitscher Joch area would represent analogous igneous activity of the 217 Ma mafic dike swarms, with the tourmalinite veins resulting from this early Mesozoic hydrothermal activity. A similar but marine setting has been described in the Austroalpine nappes north of the Tauern Window, in the evaporitic Haselgebirge Formation of the northern calcareous Alps (Schorn et al., 2013). These authors reported upper Permian (to lowermost Triassic) crystallization ages of ca. 270 to $248 \mathrm{Ma}$ for dolerite dikes, interpreted as indications of the incipient rifting and opening of the ancient Meliata Ocean after the Variscan orogeny. A metagabbro of oceanic affinity in the Tauern Window yielded an intrusion age of $157 \pm 2 \mathrm{Ma}$ (Gleißner et al., 2021), consistent with other ages of 167 to $156 \mathrm{Ma}$ along the Alpine chain (Schaltegger et al., 2002, and references therein) testifying to an already-open ocean during the Jurassic. Initial (earlier) basaltic magmatism of this spreading event might have also left traces on the passive continental margin during the opening of the Valais Ocean on the European basement, in our field area represented by the Zentralgneis.

\subsection{Concluding remarks}

In summary, our study shows that the geochemical signature of metasedimentary rocks allows determining the protoliths, diagenetic processes in the sediments, and some conclusions about the source region. We emphasize that (1) the chemical signature of the sedimentary protoliths was largely preserved during regional metamorphism and (2) individual samples may differ greatly in whole-rock geochemistry, but using averages of a sufficiently large sample set we can show that the metasedimentary rocks represent a mixture of the different rock types of the source area, as demonstrated by $\mathrm{Na}_{2} \mathrm{O} /\left(\mathrm{Na}_{2} \mathrm{O}+\mathrm{K}_{2} \mathrm{O}\right)$ and $\mathrm{MgO} /\left(\mathrm{MgO}+\mathrm{Fe}_{2} \mathrm{O}_{3}\right)$ ratios. The trace elements $\mathrm{Cr}$, $\mathrm{V}$, and $\mathrm{Ni}$ can also identify components derived from mafic-ultramafic source rocks. REE patterns of individual metamorphic rock samples are difficult to interpret (due to heterogeneous distribution of REE-rich minerals in sediment), but if averages of a unit are used, these can clearly distinguish metasedimentary rocks with an upper continental crustal signature from hydrothermally altered rocks by their steep pattern with rising contents from $\mathrm{La}$ to $\mathrm{Lu}$.

Diagenetic processes in the sediment can be reconstructed via chemical signatures; the behavior of fluid-mobile elements $\mathrm{K}, \mathrm{Rb}$, and $\mathrm{Sr}$ is especially helpful in identifying premetamorphic processes. This insight is due to the crystal chemical coupling of $\mathrm{Rb}$ to $\mathrm{K}$ and the preferential fractionation of $\mathrm{Rb}$ into mica/feldspar over hydrous fluid. Any decoupling of $\mathrm{K}$ and $\mathrm{Rb}$ requires unusual fluid compositions such as Cl-rich saline brines or hydrothermal fluids rich in $\mathrm{S}$. This is in contrast to the behavior of $\mathrm{Sr}$, which always preferentially partitions into a hydrous fluid. Although $\mathrm{Sr}$ is generally coupled to $\mathrm{Ca}$, the presence of $\mathrm{Sr}$ minerals such as strontianite or celestite can cause a strong decoupling.

$\mathrm{K}$ metasomatism of the sediments is preserved in the metamorphic product and is responsible for the large variation and locally strong enrichment in $\mathrm{K}_{2} \mathrm{O}$. Potassium and $\mathrm{Sr}$ are fixed in mica and feldspar, and although generally considered fluid-mobile during metamorphism, the variation caused by metamorphism is less important than that produced by diagenesis. This $\mathrm{K}$ metasomatism is also considered responsible for B enrichment in the precursor sediments of the study area, resulting in tourmaline-rich metamorphic rocks and explaining petrographic features such as the high tourmaline content. The B-isotope ratios and whole-rock B contents give important hints about the depositional environment in the Pfitsch-Mörchner basin, for a continental, intramontane setting with high evaporation rates.

Al- and P-bearing quartzites can be an important indication of a disconformity (however, they should not be considered a proof of a dis- or unconformity). In the PfitschMörchner basin, such rocks mark the depositional transi- 
tion from a closed-basin setting to an open basin. In their protoliths of phosphatic sandstones, $\mathrm{P}$ minerals are difficult to identify, but during metamorphism and the formation of macroscopically identifiable blue lazulite, easily found during fieldwork, the presence of these quartzites can hint at a possible disconformity.

Basinal brines, enriched in $\mathrm{B}$, can lead to the formation of tourmalinite, with crosscutting field relations. Characteristic for the origin of these tourmalinites is fluid immiscibility of B-rich and Si-rich gel-like fluids. In the case of the Pfitsch-Mörchner basin, the heat source of this hydrothermal event is unknown, but we speculate that it was associated with Permo-Triassic magmatism that took place following incipient rifting after the Variscan orogeny and before the onset of the Alpine orogeny.

Data availability. Data and the Supplement used in this article are available at https://doi.org/10.5880/fidgeo.2021.013 (Franz et al., 2021).

Sample availability. Samples are stored at the Free University of Berlin and at the Technical University of Berlin. No IGSNs have been assigned.

Author contributions. GF contributed to conceptualization, fieldwork, sampling, interpretation, and writing. EB contributed to fieldwork, sampling, data production, interpretation, and writing. MK contributed to fieldwork, sampling, data production, interpretation, and writing; AM contributed to boron data production. AL contributed to fieldwork, sampling, data production, interpretation, and writing. DS contributed to fieldwork, sampling, data production, interpretation, and writing.

Competing interests. Author Gerhard Franz is a member of the managing committee for this journal. The other authors declare that they have no conflict of interest.

Disclaimer. Publisher's note: Copernicus Publications remains neutral with regard to jurisdictional claims in published maps and institutional affiliations.

Acknowledgements. We thank our students who over several years contributed data during field courses, as well as diplomas and bachelor's and master's theses. Discussions and support with literature by Jane Selverstone, Laura Gaggero, and Volkmar Mair are gratefully acknowledged. Reinhard Gaupp and John Slack carefully read an earlier version of the manuscript and helped significantly to clarify several points. Bernard Bonin and the anonymous referee are thanked for their helpful reviews, and Klaus Mezger and Elisabetta Rampone are thanked for editorial handling. Gerhard Franz extends special thanks to Giulio Morteani for introducing him to this fasci- nating field area and last but not least to the Volgger family from Pfitscher Joch Haus for long-lasting hospitality and friendship.

Financial support. This research has been supported by the Deutsche Forschungsgemeinschaft (grant nos. FR 557/31-1, HE 2015/16-1, and INST 144/308-1).

This open-access publication was funded

by Technische Universität Berlin.

Review statement. This paper was edited by Elisabetta Rampone and reviewed by Bernard Bonin and one anonymous referee.

\section{References}

Aubert, D., Stille, P., and Probst, A.: REE fractionation during granite weathering and removal by waters and suspended loads: $\mathrm{Sr}$ and Nd isotopic evidence, Geochim. Cosmochim. Acta, 65, 387406, 2001

Ague, J. J.: Extreme channelization of fluid and the problem of element mobility during Barrovian metamorphism, Am. Mineral., 96, 333-352, 2011.

Bao, Z. and Zhao, Z.: Geochemistry of mineralization with exchangeable REY in the weathering crusts of granitic rocks in South China, Ore Geol. Rev., 33, 519-535, 2008.

Barnes, J. D., Selverstone, J., and Sharp, Z. D.: Interactions between serpentinite devolatilization, metasomatism and strike-slip strain localization during deep-crustal shearing in the eastern Alps, J. Metam. Geol., 22, 283-300, 2004.

Barrientos, X. and Selverstone, J.: Metamorphosed soils as stratigraphic indicators in deformed terranes: An example from the Eastern Alps, Geology, 15, 841-844, 1987.

Bhatia, M. R.: Plate tectonics and geochemical composition of sandstones, J. Geol., 91, 611-627, 1983.

Bebout, G. E. and Graham, C. M.: Cycling of B, Li, and LILE (K, $\mathrm{Cs}, \mathrm{Rb}, \mathrm{Ba}, \mathrm{Sr}$ ) into subduction zones: SIMS evidence from micas in high-P/T metasedimentary rocks, Chem. Geol., 239, 284 304, 2007.

Bebout, G. E. and Nakamura, E.: Record in metamorphic tourmaline of subduction-zone devolatilization and boron cycling, $\mathrm{Ge}-$ ology, 31, 407-410, 2003.

Behrmann, J. H.: Crustal-scale extension in a convergent orogen: The Sterzing-Steinach mylonite zone in the Eastern Alps, Geodyn. Acta, 2, 63-73, 1988.

Behrmann, J. H. and Frisch, W.: Sinistral ductile shearing associated with metamorphic decompression in the Tauern window, Eastern Alps, Jb. Geol. B.-A., 133, 135-146, 1990.

Berryman, E. J., Kutzschbach, M., Trumbull, R. B., Meixner, A., van Hinsberg, V., Kasemann, S. A., and Franz, G.: Tourmaline as a petrogenetic indicator in the Pfitsch Formation, western Tauern Window, eastern Alps, Lithos, 284-285, 138-155, 2017.

Brandner, R., Töchterle, A., Pomela, H., and Reiter, F.: Geological map of the Brenner-Basistunnel 1:50,000, Geol. Surv. Bozen, Italy, 2011.

Brunsmann, A., Franz, G., and Erzinger, J.: REE mobilization during small-scale high-pressure fluid-rock interaction and 
zoisite/fluid partitioning of $\mathrm{La}$ to $\mathrm{Eu}$, Geochim. Cosmochim. Acta, 65, 559-570, 2001.

Cassinis, G., Cortesogno, L., Gaggero, L., and Buzzi, L.: Permian to Triassic geodynamic and magmatic evolution of the Brescian Prealps (eastern Lombardy, Italy), Boll. Soc. Geol. Ital. (Ital. J. Geosc.) 127, 501-518, 2008.

Cesare, B., Rubatto, D. Hermann, J., and Barzi, L.: Evidence for late Carboniferous subduction-type magmatism in mafic-ultramafic cumulates of the SW Tauern window (eastern Alps), Contrib. Miner. Petrol., 142, 449-464, 2002.

Christa, E.: Das Gebiet des Oberen Zemmgrundes in den Zillertaler Alpen, Jb. Geol. B.-A., 81, 533-635, 1931.

Cortesogno, L., Fiorini, E., Gaggero, L., Molina, M., and Ronchi, A.: New stratigraphic and petrographic data on the Permian Tione basin (lower Val Rendena, Trentino, Italy), Atti Tic. Sc. Terra (Serie Spez.), 7, 125-138, 1998.

Day-Stirrat, R. J., Milliken, K. L., Dutton, S. P., Loucks, R. G., Hillier, S., Aplin, A. C., and Schleicher, A. M.: Open-system chemical behavior in deep Wilcox Group mudstones, Texas Gulf Coast, USA, Mar. Petrol. Geol., 27, 1804-1818, 2010.

De Capitani, L., Moroni, M., and Rodeghiero, F.: Geological and geochemical characteristics of Permian tourmalinization at Val Trompia (southern Alps, northern Italy) and relationship with the Orobictourmalinites, Periodica Mineral., 68, 185-212, 1999.

De Vecchi, G. P. and Baggio, P.: The Penninic zone of the Vizze region in the western Tauern Window (Italian eastern Alps), Boll. Soc. Geol. Italia, 101, 89-116, 1982.

Elter, F. M., Gaggero, L., Mantovani, F., Pandeli, E., and Costamagna, L. G.: The Atlas-east Variscan-Elbe shear system and its role in the formation of the pull-apart late Paleozoic basins, Int. J. Earth Sci., 109, 739-760, 2020.

Fedo, C. M., Nesbitt, H. W., and Young, G. M.: Unraveling the effects of potassium metasomatism in sedimentary rocks and paleosols, with implications for paleoweathering conditions and provenance, Geology, 23, 921-924, 1995.

Feijth, J.: Palaeozoic and Mesozoic tectono-metamorphic development and geochronology of the Orobic chain (southern Alps, Lombardy, Italy), $\mathrm{PhD}$ thesis, Technical University Berlin, 166 pp., 2002.

Finger, F., Frasl, G., Haunschmidt, B., Lettner, H., von Quadt, A., Schermaier, A., Schindlmayr, A. O., and Steyrer, H. P.: The Zentralgneise of the Tauern window (Eastern Alps): insight into an intra-alpine Vasican batholith, in: Pre-Mesozoic geology in the Alps, edited by: von Raumer, J. F. and Neubauer, F., Springer, Berlin, Heidelberg, New York, 375-391, 1993.

Foley, N. and Ayuso, R.: REE enrichment in granite-derived regolith deposits of the Southeastern United States: Prospective source rocks and accumulation processes, British Columbia Geol. Surv. Paper, 2015-3, 131-138, 2015.

Franz, G., Grundmann, G., and Ackermand, D.: Rock forming beryl from a regional metamorphic terrain (Tauern Window, Austria): Parageneses and crystal chemistry, Tschermaks Min. Petr. Mitt. 35, 167-192, 1986.

Franz, G., Berryman, E., Kutzschbach, M., Meixner, A., Kasemann, S., Lucassen, F., Loges, A., and Schultze, D.: Whole-rock geochemistry of rock units from the Pfitscher Joch area, Western Tauern Window, GFZ Data Services, https://doi.org/10.5880/fidgeo.2021.013, 2021.
Frisch, W.: Tectonics of the western Tauern Window, Mitt. Österr. Geol. Ges. 71, 65-71, 1980.

Gaboreau, S., Beaufort, D., Viellard, P., Patrier, P., and Bruneton, P.: Aluminium-phosphate-sulfate minerals associated with Proterozoic unconformity-type uranium deposits in the east Alligator Rivers uranium field, Northern Territory, Australia, Can. Mineral., 43, 813-827, 2005.

Gaboreau, S., Cuney, M., Quirt, D., Beaufort, D., Patrier, P., and Mathieu, R.: Significance of aluminum phosphate-sulfate minerals associated with unconformity-type deposits: The Athabasca basin, Canada, Am. Mineral., 92, 267-280, 2007.

Galán-Abellán, A. B., Barrenechea, J. F., Benito, M. I., De la Horra, R., Luque, F. J., Alonso-Azcárate, J., López-Gómez, A. J., and Lago, M.: Palaeoenvironmental implications of aluminum phosphate-sulphate minerals in Early-Middle Triassic continental sediments, SE Iberian Range (Spain), Sed. Geol., 289, 169181, 2013.

Gleißner, P., Franz, G., and Frei, D.: Contemporaneous opening of the Alpine Tethys in the Eastern and Western Alps: Constraints from a Late Jurassic gabbro intrusion age in the Glockner Nappe, Tauern Window, Austria, Int. J. Earth Sci., accepted, 2021.

Glodny, J., Ring, U., and Kühn, A.: Coeval high-pressure metamorphism, thrusting, strike-slip, and extensional shearing in the Tauern Window, Eastern Alps, Tectonics, 27, TC4004, https://doi.org/10.1029/2007TC002193, 2008.

Grew, E. S., Hystad, G., Hazen, R. M., Krivovichev, S. V., and Gorelova, L. A.: How many boron minerals occur in Earth's upper crust?, Am. Mineral., 102, 1573-1587, 2017.

Hall, R. B., Foord, E. E., Keller, D. J., and Keller, W. D.: Phosphates in some Missouri refractory clays, Clays Clay Minerals, 45, 353364, 1997.

Henry, D. J., Dutrow, B. L., and Selverstone, J.: Compositional asymmetry in replacement tourmaline - An example from the Tauern Window, eastern Alps, Geol. Mat. Res., 4, 1-18, 2002.

Herron, M. M.: Geochemical classification of terrigenous sands and shales from core or log data, J. Sed. Petrol., 58, 820-829, 1988.

Hikov, A.: Geochemistry of hydrothermally altered rocks from the Asarel porphyry copper deposit, central Srednogorie, Geol. Balcanica, 42, 3-28, 2013.

Karakaya, M. Ç., Karakaya, N., Küpeli, Ş., and Yavuz, F.: Mineralogy and geochemical behavior of trace elements of hydrothermal alteration types in the volcanogenic massive sulfide deposits, NE Turkey, Ore Geol. Rev., 48, 197-224, 2012.

Kasemann, S., Meixner, A., Rocholl, A., Vennemann, T., Rosner, M., Schmitt, A., and Wiedenbeck, M.: Boron and oxygen isotope composition of certified reference materials NIST SRMs 610/612 and reference materials JB-2 and JR-2, Geostandard Newsletter, 25, 405-416, 2001.

Kasemann, S. A., Meixner, A., Erzinger, J., Viramonte, J. G., Alonso, R. N., and Franz, G.: Boron isotope composition of geothermal fluids and borate minerals from salar deposits (central Andes/NW Argentina), J. S. Am. Earth Sci., 16, 685-697, 2004.

Khashgerel, B.-E., Kavalieris, I., and Hayashi, K.-I.: Mineralogy, textures, and whole-rock geochemistry of advanced argillic alteration: Hugo Dummett porphyry $\mathrm{Cu}-\mathrm{Au}$ deposit, Oyu Tolgoi mineral district, Mongolia, Mineral., Dep., 43, 913-932, 2008.

Kravchuk, K. G. and Valyashko, V. M.: Equilibrium diagram of the system $\mathrm{Na}_{2} \mathrm{O}-\mathrm{SiO}_{2}-\mathrm{H}_{2} \mathrm{O}$, in: Methods of experimental investi- 
gations of hydrothermal equilibria, edited by: Godovikov, A. A., Nauka, Novosibirsk, 105-117, 1979 (in Russian).

Lammerer, B.: Das Authochton im Westlichen Tauernfenster, Jb. Geol. B.-A. Wien, Austria, 129, 51-67, 1986.

Lammerer, B. and Morteani, G.: Exkursion E8: Schlegeis und Pfitscher Joch, Zillertaler Alpen, Österr. Mineral. Ges. Wien, 135, 185-197, 1990.

Lammerer, B. and Weger, M.: Footwall uplift in an orogeneic wedge: The Tauern Window in the Eastern Alps of Europe, Tectonophysics, 285, 213-230, 1998.

Lammerer, B., Gebrande, H., Lüschen, E., and Veselá, P.: A crustalscale cross-section through the Tauern Window (eastern Alps) from geophysical and geological data, Geol. Soc., London Spec. Pub., 298, 219-229, 2008.

Lammerer, B., Selverstone, J., and Franz, G.: Field trip to the Tauern Window region along the TRANSALP seismic profile, eastern Alps, Austria, Geol. Soc. Amer., Field Guide 22, 1-20, 2011.

Land, L. S., Mack, L. E., Milliken, K. L., and Lynch, F. L.: Burial diagenesis of argillaceous sediment, south Texas Gulf of Mexico sedimentary basin: A reexamination, Geol. Soc. Am. Bull., 109, 2-15, 1997.

Leising, J. F., Tyler, S. W., and Miller, W. W.: Convection of saline brines in enclosed lacustrine basins: A mechanism for potassium metasomatism, Geol. Soc. Am. Bull., 107, 1157-1163, 1995.

Li, X.-C., Fan, H.-R., Santosh, M., Hu, F.-F., Yang, K.-F., and Lan, T.-G.: Hydrothermal alteration associated with Mesozoic granite-hosted gold mineralization at the Sanshandao deposit, Jiaodong gold province, China, Ore Geol. Rev., 53, 403-421, 2013.

Lottermoser, B. G.: Rare earth elements and hydrothermal ore formation processes, Ore Geol. Rev. 7, 25-41, 1992.

Marfil, S. A., Maiza, P. J., and Montecchiari, N.: Alteration zonation in the Loma Blanca kaolin deposit, Los Menucos, Province of Rio Negro, Argentina, Clay Minerals, 45, 145-157, 2010.

MacLean, W. H., and Hoy, L. D.: Geochemistry of hydrothermally altered rocks at the Horne mine, Noranda, Quebec, Econ. Geol. 86, 506-528, 1991.

McArthur, J. M., Howarth, R. J. and Shields, G. A.: Strontium Isotope Stratigraphy, The Geologic Time Scale, Cambridge University Press, 127-144, 2012.

Melcher, F., Prochaska, W., Raith, J. G., and Saini-Eidukat, B.: The metamorphosed molybdenum vein-deposit of the Alpeinerscharte, Tyrol (Austria) and its relation to Variscan granitoids, Mineral. Deposita, 31, 277-289, 1996.

Melzer, S. and Wunder, B.: Island-arc basalt alkali rations - Constraints from phengite-fluid partitioning experiments, Geology, 28, 583-586, 2000.

Melzer, S. and Wunder, B.: K-Rb-Cs partitioning between phlogopite and fluid: Experiments and consequences for the LILE signatures of island arc basalts, Lithos 59, 69-90, 2001.

Middlemost, E. A.: Naming materials in the magma/igneous rock system, Earth-Sci. Rev., 37, 215-224, 1994.

Mordberg, L. E., Stanley, C. J., and Germann, K..: Rare earth element anomalies in crandallite group minerals from the Schugorsk bauxite deposit, Timan, Russia. Europ. J. Min., 12, 1229-1243, 2000

Morteani, G.: Petrology of the Tauern Window, Austrian Alps, Fortschr. Mineral., 52, 195-220, 1974.
Morteani, G. and Ackermand, D.: Aluminium phosphates in muscovite-kyanite metaquartzites from Passo di Vizze (Alto Adige, NE Italy), Eur. J. Mineral., 8, 853-869, 1996.

Morteani, G., Ackermand, D., and Trappe, J.: Aluminium phosphate in Proterozoic metaquartzites: Implications for the Precambrian oceanic P budget and development of life, Geol. Soc. Am. Bull. Spec. Pap., 423, 579-592, 2007.

Mostler, H., Heissel, G., and Gasser, G.: Untersuchung von Erzlagerstätten im Innsbrucker Quarzphyllit und auf der Alpeiner Scharte, Arch. Lagerstättenf. Geol. BA, 1, 77-83, 1982.

Nesbitt, H. W. and Young, G. M.: Prediction of some weathering trends of plutonic and volcanic rocks based on thermodynamic and kinetic considerations, Geochim. Cosmochim. Acta, 48, 1523-1534, 1984.

Nikishin, A. M., Ziegler, P. A., Abott, D., Brunet, M.-F., and Cloething, S.: Permo-Triassic intraplate magmatism and rifting in Eurasia: implications for mantle plumes and mantle dynamics, Tectonophics, 351, 3-39, 2002.

Oeser, R. A., Stroncik, N., Moskwa, L.-M., Bernhard, N., Schaller, M., Canessa, R., van den Brink, L., Köster, M., Brucker, E., Stock, S., Fuentes, J. P., Godoy, R., Matus, F. J., Oses Pedraza, R., Osses McIntyre, P., Paulino, L., Seguel, O., Bader, M. Y., Boy, J., Dippold, M. A., Ehlers, T. A., Kühn, P., Kuzyakov, Y., Leinweber, P., Scholten, T., Spielvogel, S., Spohn, M., Übernickel, K., Tielbörger, K., Wagner, D., and von Blanckenburg, F.: Chemistry and microbiology of the critical zone along a steep climate and vegetation gradient in the Chilean coastal Cordillera, Catena, 170, 183-203, 2018.

Owens, B. E. and Pasek, M. A.: Kyanite quartzites in the Piedmont province of Virginia: Evidence for a possible high-sulfidation system, Econ. Geol., 102, 495-509, 2007.

Owens, B. E. and Hollingsworth, J. W.: Mineralogical and geochemical constraints on the origin of kyanite quartzites in the Kings Mountain terrain, North Carolina and South Carolina, Southeast. Geol., 53, 81-96, 2018.

Padrones, J. T., Imai, A., and Takahashi, R.: Geochemical behavior of rare earth elements in weathered granitic rocks in northern Palawan, Philippines, Res. Geol., 67, 321-353, 2017.

Palmer, M. R. and Swihart, G. H.: Boron isotope geochemistry: an overview, Rev. Mineral. Geochem., 33, 709-744, 1996.

Pearce, J. A., Harris, N. B. W., and Tindle, A. G.: Trace element discrimination diagrams for the tectonic interpretation of granitic rocks, J. Petrol., 25, 956-983, 1984.

Pearce, J. A. and Cann, J. R.: Tectonic setting of basic volcanic rocks determined using trace element analyses, Earth Planet. Sc. Lett., 19, 290-300, 1973.

Pe-Piper, G. and Dolansky, L. M.: Early diagenetic origin of Al phosphate-sulfate minerals (woodhouseite and crandallite series) in terrestrial sandstones, Nova Scotia, Canada, Amer. Mineral., 90, 1434-1441, 2005.

Pourmand, A. N., Dauphas, N., and Ireland, T. J.: A novel extraction chromatography and MC-IC-MS technique for rapid analysis of REE, Sc and Y: Revising CI-chondrite and Post-Archean Australian Shale (PAAS), Chem. Geol., 291, 38-54, 2012.

Rasmussen, B: Early-diagenetic REE-phosphate minerals (florencite, crandallite, gorceixite and xenotime) in marine sandstones: A major sink for oceanic phosphorus, Am. J. Sci., 296, 601-632, 1996. 
Ratschbacher, L., Merle, O., Davy, P., and Cobbold, P.: Lateral extrusion in the eastern Alps, Part 1: Boundary conditions and experiments scaled for gravity, Tectonics, 10, 245-256, 1991.

Ricchi, E., Bergemann, C. A., Gnos, E., Berger, A., Rubatto, D., Whitehouse, M. J., and Walter, F.: Cenozoic deformation in the Tauern Window (Eastern Alps) constrained by in situ $\mathrm{Th}-\mathrm{Pb}$ dating of fissure monazite, Solid Earth, 11, 437-467, https://doi.org/10.5194/se-11-437-2020, 2020.

Romer, R. L., Meixner, A., and Hahne, K.: Lithium and boron isotopic composition of sedimentary rocks - the role of source history and depositional environment: a $250 \mathrm{Ma}$ record from the Cadomian orogeny to the Variscan orogeny, Gondwana Res., 26, 1093-1110, 2014.

Rosenberg, C. L. and Schneider, S.: The western termination of the SEMP Fault (eastern Alps) and its bearing on the exhumation of the Tauern Window, Geol. Soc., London, Spec. Publ., 298, 197218, 2008.

Rosenberg, C. L., Schneider, S., Scharf, A., Bertrand, A., Hammerschmidt, K., Rabaute, A., and Brun, J. P.: Relating collisional kinematics to exhumation processes in the Eastern Alps, Earth Sci. Rev., 176, 311-344, 2018.

Rudnick, R. L. and Gao, S.: Composition of the continental crust, Treatise on Geochemistry, Elsevier Ltd. 3, 1-64, 2003.

Schaltegger, U., Desmurs, L., Manatschal, G., Müntener, O., Meier, M., Frank, M., and Bernoulli, D.: The transition from rifting to sea-floor spreading within a magma-poor rifted margin: Field and isotopic constraints, Terra Nova, 14, 156-162, 2002.

Schmid, S. M., Scharf, A., Handy, M. R., and Rosenberg, C. L.: The Tauern Window (eastern Alps, Austria): A new tectonic map with cross-sections and a tectonic metamorphic synthesis, Swiss J. Geosci., 106, 1-32, 2013.

Schön, C. and Lammerer, B.: Die postvariskischen Metakonglomerate des westlichen Tauernfensters, Österreich, Mitt. österr. geol. Ges., 81, 219-232, 1989.

Schorn, A., Neubauer, F., Genser, J., and Bernroider, M.: The Haselgebirge evaporitic melange in central northern calcareous Alps (Austria): Part of the Permian to Lower Triassic rift of the Meliata ocean?, Tectonophysics, 583, 28-48, 2013.

Schmid, S. M., Scharf, A., Handy, M. R., and Rosenberg, C. L.: The Tauern Window (Eastern Alps, Austria): a new tectonic map with cross-sections and a tectonometamorphic synthesis, Swiss J. Geosci., 106, 1-32, 2013.

Schulz, B.: Alpidische Metamorphose im westlichen Tauernfenster (Ostalpen): Interpretation mit P-T-Pfaden von Amphiboliten, Zbl. Geol. Paläont. Teil I, H. 3/4, 315-328, 1996.

Schulz, B., Triboulet, C., and Adren, A.: Microstructures and mineral chemistry in amphibolites from the western Tauern Window (eastern Alps), and P-T deformation paths of the Alpine greenschist-amphibolite facies metamorphism, Mineral. Mag., 59, 641-659, 1995.

Schuster, R. and Stüwe, K.: Permian metamorphic event in the Alps, Geology, 36, 603-606, 2008.

Scotese, C. R., and Schettino, A.: Late Permian-Early Jurassic paleogeography of western Tethys and the world, in: Permo-Triassic Salt Provinces of Europe, North Africa and the Atlantic Margins, Elsevier, 57-95, 2017.

Selverstone, J.: Petrologic constraints on imbrication, metamorphism, and uplift in the SW Tauern Window, eastern Alps, Tectonics, 4, 607-704, 1985.
Selverstone, J.: Evidence for east-west crustal extension in the eastern Alps: Implications for the unroofing history of the Tauern Window, Tectonics, 7, 87-105, 1988.

Selverstone, J.: Micro- to macroscale interactions between deformational and metamorphic processes, Tauern Window, eastern Alps, Schweiz. Mineral. Petrogr. Mitt., 73, 229-239, 1993.

Selverstone, J. and Hyatt, J.: Chemical and physical responses to deformation in micaceous quartzites from the Tauern Window, eastern Alps, J. Metam. Geol., 21, 335-345, 2003.

Selverstone, J. and Muñoz, J. L.: Fluid heterogeneities and hornblende stability in interlayered graphitic and nongraphitic schists (Tauern Window, eastern Alps), Contrib. Mineral. Petrol. 96, 426-440, 1987.

Selverstone, J. and Spear, F. S.: Metamorphic P-T paths from pelitic schists and greenstones from the south-west Tauern Window, eastern Alps, J. Metam. Geol., 3, 439-465, 1985.

Selverstone, J., Spear, F. S., Franz, G., and Morteani, G.: Highpressure metamorphism in the SW Tauern Window, Austria: P-T paths from hornblende-kyanite-staurolite-schists, J. Petrol., 25, 501-531, 1984.

Selverstone, J., Morteani, G., and Staude, J. M.: Fluid channeling during ductile shearing: Transformation of granodiorite into aluminous schist in the Tauern Window, eastern Alps, J. Metam. Geol., 9, 419-431, 1991.

Skelton, A. D. L., Graham, C. M., and Bickle, M. J.: Lithological and structural controls on regional 3-D fluid flow patterns during greenschist facies metamorphism of the Dalradian of the SW Scottish Highlands, J. Petrol., 36, 563-586, 1995.

Slack, J. F., Passchier, C. W., and Zhang, J. S.: Metasomatic tourmalinite formation along basement-cover décollements, Orobic Alps, Italy, Schweiz. Mineral. Petrogr. Mitt., 76, 193-207, 1996.

Smith, G. I., Medrano, M. D., and Anovitz, L. M.: Boron: Mineralogy, petrology and geochemistry, Rev. Mineralogy, 33, 263$298,1996$.

Smirnov, S. Z., Thomas, V. G., Demin, S. P., and Drebushchak, V. A.: Experimental study of boron solubility and speciation in the $\mathrm{Na}_{2} \mathrm{O}-\mathrm{B}_{2} \mathrm{O}_{3}-\mathrm{SiO}_{2}-\mathrm{H}_{2} \mathrm{O}$ system, Chem. Geol., 223, 16-34, 2005.

Steffen, K., Selverstone, J., and Brearley, A.: Episodic weakening and strengthening during synmetamorphic deformation in a deep-crustal shear zone in the Alps, in: The Nature and Tectonic Significance of Fault Zone Weakening, edited by: Holdsworth, R. E., Strachan, R. A., Magloughlin, J. F., and Knipe, R. J., Geological Society, London, 141-156, 2001.

Steffen, K. and Selverstone, J.: Retrieval of P-T information from shear zones: Thermobarometric consequences of changes in plagioclase deformation mechanisms, Contrib. Mineral. Petrol., 151, 600-614, 2006.

Tauson, V. L., Taroev, V. K., Akimov, V. V., Gottlicher, J., Pentinghaus, H., and Rocholl, A.: New data on Cs and Rb distribution between potassium feldspar and alkaline fluid: A study of the trapping effect, Geochem. Int., 39, 725-734, 2001.

Thyne, G.: A model for diagenetic mass transfer between adjacent sandstone and shale, Marine Petrol. Geol., 18, 743-755, 2001.

Tonarini, S., Pennisi, M., and Leeman, W. P.: Precise boron isotopic analysis of complex silicate (rock) samples using alkali carbonate fusion and ion-exchange separation, Chem. Geol., 142, 129137, 1997. 
Trumbull, R. B., Krienitz, M.-S., Grundmann, G., and Wiedenbeck M.: Tourmaline geochemistry and $\delta^{11} \mathrm{~B}$ variations as a guide to fluid-rock interaction in the Habachtal emerald deposit, Tauern Window, Austria, Contrib. Mineral. Petrol., 157, 411-427, 2008.

Turekian, K. K. and Wedepohl, K. H.: Distribution of the elements in some major units of the Earth's crust, Geol. Soc. Amer. Bull., 72, 175-192, 1961.

Valyashko, V. M.: Phase equilibria and properties of hydrothermal systems, Nauka, Moscow, 270 pp., 1990.

Veselá, P. and Lammerer, B.: The Pfitsch-Mörchner basin, an example of the post-Variscan sedimentary evolution in the Tauern Window (eastern Alps), Swiss J. Geosci., 101, 73-88, 2008.

Veselá, P., Söllner, F., Finger, F., and Gerdes, A.: Magmatosedimentary Carboniferous to Jurassic evolution of the western Tauern window, eastern Alps (constraints from U-Pb zircon dating and geochemistry), Int. J. Earth Sci., 100, 993-1027, 2011.

von Goerne, G., Franz, G., and Heinrich, W.: Synthesis of tourmaline solid solutions in the system $\mathrm{Na}_{2} \mathrm{O}-\mathrm{MgO}-\mathrm{Al}_{2} \mathrm{O}_{3}-\mathrm{SiO}_{2}-$ $\mathrm{B}_{2} \mathrm{O}_{3}-\mathrm{H}_{2} \mathrm{O}-\mathrm{HCl}$ and the distribution of $\mathrm{Na}$ between tourmaline and fluid at 300 to $700{ }^{\circ} \mathrm{C}$ and $200 \mathrm{MPa}$, Contrib. Mineral. Petr., $141,160-173,2001$
Williams, L. B., Hervig, R. L., Holloway, J. R., and Hutcheon, I.: Boron isotope geochemistry during diagenesis, Part 1. Experimental determination of fractionation during illitization of smectite, Geochim. Cosmochim. Acta, 65, 1769-1782, 2001.

Williams, J. C., Stebbins, A., and Brookfield, M. E.: Geochemical changes across a marginal marine Permo-Triassic boundary section on the Adria carbonate platform at Brsnina, Slovenia, Int. J. Earth Sci., 110, 923-942, 2021.

Wunder, B., Meixner, A., Romer, R. L., Wirth, R., and Heinrich, W.: The geochemical cycle of boron: Constraints from boron isotope partitioning experiments between mica and fluid, Lithos 84, 206216, 2005.

Yuan, S., Neubauer, F., Liu, Y., Genser, J., Liu, B., Yu, S., Chang, R., and Guan, Q.: Widespread Permian granite magmatism in Lower Austroalpine units: significance for Permian rifting in the Eastern Alps, Swiss J. Geosci., 113, 18, https://doi.org/10.1186/s00015020-00371-5, 2020. 